Cornell Law Library

Scholarship@Cornell Law: A Digital Repository

Cornell Law Faculty Publications

9-8-2004

\title{
The Role of Private International Law in the United States: Beating the Not-Quite-Dead Horse of Jurisdiction
}

Kevin M. Clermont

Cornell Law School, kmc12@cornell.edu

Follow this and additional works at: http://scholarship.law.cornell.edu/lsrp_papers

Part of the Conflicts of Law Commons, and the Jurisdiction Commons

\section{Recommended Citation}

Clermont, Kevin M., "The Role of Private International Law in the United States: Beating the Not-Quite-Dead Horse of Jurisdiction" (2004). Cornell Law Faculty Publications. Paper 14.

http://scholarship.law.cornell.edu/lsrp_papers/14 
Chapter 4.

THE ROLE OF PRIVATE INTERNATIONAL LAW IN THE UNITED STATES: BEATING THE NOT-QUITEDEAD HORSE OF JURISDICTION

Kevin M. Clermont ${ }^{*}$

\section{Introduction}

The materials announcing this conference struck fear in my heart, doing so by calling for the "cooperative development of private international law and international private law." This sounds innocuous enough, even desirable. I know what they meant, I think, but all I could think of was a course that I took in law school entitled Comparative Conflict of Laws. ${ }^{1}$ We spent literally the first six weeks of the 13 week course on the distinction between private international law and international private law, only to conclude that there was no difference.

Building on that solid intellectual foundation, I can report that the more common of the two terms-private international lawarose first in the United States ${ }^{2}$ (although today it is little used here, having been driven back by the older term "conflict of laws" $)$. "Private international law" emigrated to France within a decade, ${ }^{4}$ and then the term spread fast through the $19^{\text {th }}$ century mindset. ${ }^{5}$ Today we understand that private international law is neither truly international nor exclusively private, but is instead a branch of domestic law treating legal situations with non-domestic elements that pose a conflict of sovereign authority. Its precise scope varies from country to country. In Germany, the subject tends to be narrow, focusing on choice of law. ${ }^{6}$ In the United States, it covers choice of law, but also reaches territorial authority to adjudicate and the

${ }^{*}$ Flanagan Professor of Law, Cornell University.

${ }^{1}$ The course was taught in the fall of 1970 at Harvard Law School by Professor Rodolfo de Nova, visiting from the University of Pavia.

${ }^{2}$ Joseph Story, Commentaries on the Conflict of Laws $\$ 9$ (1834).

${ }^{3}$ See Claire M. Germain, Germain's Transnational Law Research $\$ 1.01 .2$ (1991).

${ }^{4}$ Foelix, Traité du droit international privé, ou du conflit des lois de différentes nations en matière de droit privé (1843).

${ }^{5}$ See Gerhard Kegel, Introduction: Private International Law, 3 Int'l Ency. Comp. L. 1-1, 1-3 (1986).

${ }^{6}$ See Gerhard Kegel, Introduction: Private International Law, 3 Int'l Ency. Comp. L. 1-1, 1-1 (1986). 
treatment of foreign judgments. ${ }^{7}$ In France, private international law extends even further to matters of nationality and the legal status of foreigners. ${ }^{8}$ As I still have my old class notes, and as articles exist with titles like "What Is Private International Law?", I could rehearse the past battles of definition (or could argue the possible superiority of alternative terms). Ultimately, "[i]t is a matter of convenience whether a broad or a narrow definition of private international law is adopted."10

In this conference, with its focus on Article 65 of the Treaty Establishing the European Community, ${ }^{11}$ it seems to me that a convenient definition would include jurisdiction, choice of law, and judgments but would also extend into international civil procedure far enough to pick up judicial cooperation on matters such as service and evidence. ${ }^{12}$

${ }^{7}$ See William M. Richman \& William L. Reynolds, Understanding Conflict of Laws $\S 1$, at 1 (3d ed. 2002) ("Conflicts, like Caesar's Gaul, is generally said to be divided into three parts: jurisdiction, choice of law, and judgments."); David D. Siegel, Conflicts in a Nutshell § 3 (2d ed. 1994).

${ }^{8}$ See Bernard Audit, Droit international privé 1-19 (3d ed. 2000)

${ }^{9}$ W.E. Beckett, What Is Private International Law?, 7 Brit. Y.B. Int'l L. 73, 94 (1926) (arguing for strictly limiting the subject to jurisdiction and choice of law).

${ }^{10}$ Gerhard Kegel, Introduction: Private International Law, 3 Int'l Ency. Comp. L. 1-1, 1-2 (1986). But see W.E. Beckett, What Is Private International Law?, 7 Brit. Y.B. Int'l L. 73, 95 (1926) (arguing that definition has consequences).

${ }^{11}$ Article 65, effective in 1999, provides:

Measures in the field of judicial co-operation in civil matters having cross-border implications, to be taken in accordance with Article 67 and insofar as necessary for the proper functioning of the internal market, shall include:

(a) improving and simplifying:

the system for crostrajudicial documents, co-operation in the taking of evidence,

the recognition and enforcement of decisions in civil and commercial cases, includthe recognition and enforcement of d
ing decisions in extrajudicial cases;

(b) promoting the compatibility of the rules applicable in the Member States concerning the conflict of laws and of jurisdiction;

(c) eliminating obstacles to the good functioning of civil proceedings, if necessary by promoting the compatibility of the rules on civil procedure applicable in the Member States.

1 Encyclopedia of European Union Law 3-0074 (Neville March Hunnings gen. ed. 1 Encyclopedia of European Union Law 3 ; see Michael Wilderspin, New Possibilities for Cooperation with the European Union--The Transfer of Competence for Judicial Cooperation from Member States to Community Institutions: The Foundations and the Implementation of the Transfer of Competence in the Area of Judicial Cooperation in Civi Matters to the Community Institutions, 21 J.L. \& Com. 181 (2002) (nicely chronicling the communitarization of private international law).

${ }^{12}$ See Stephen B. Burbank, The Reluctant Partner: Making Procedural Law for International Civil Litigation, Law \& Contemp. Probs., Summer 1994, at 103, 127-135 (treating judicial cooperation).

\section{Preeminence of jurisdiction in U.S. private international law}

Given this broad definition of private international law, and given the federal structure of the United States, it is safe to say that private international law, by whatever name, has huge importance in the United States. That fact explains why jurisdiction typically occupies (although usually with an appended study of res judicata ${ }^{13}$ ) the most substantial part of the major first-year law course on civil procedure. ${ }^{14}$ Also, the U.S. situation incidentally helps to explain why the typical upper class course on conflicts of law, which mostly emphasizes choice of law, ignores international cases in favor of interstate cases. ${ }^{15}$

Outside the academy, lawyers in the United States expend significant time, energy, and other resources on the process of forum selection. They know that the "name of the game is forumshopping." ${ }^{16}$ Few cases reach trial in the U.S. civil litigation system today; after perhaps some initial skirmishing, most cases settle. Yet all cases entail forum selection, be it selection of local venue, interstate shopping, state/federal selection, or international shopping. First, consider the individual case. The plaintiff's opening moves include shopping for the most favorable forum. Then, the defendant's parries and thrusts might include some forum-shopping in return, possibly by a motion for transfer of venue. Forum is worth fighting over because outcome often turns on forum, as I shall document below. When the dust settles, the case does too-but on terms that reflect the results of the skirmishing; thus, the fight over forum can be the critical dispute in the case. ${ }^{17}$ Second, forum selection is very important not only to the litigator but, also, to the office lawyer

${ }^{13}$ See generally Robert C. Casad \& Kevin M. Clermont, Res Judicata: A Handbook on Its Theory, Doctrine, and Practice (2001).

${ }^{14}$ At Cornell Law School, jurisdiction and judgments occupy half of the sixcredit course in civil procedure, which equals the biggest course in the curriculum.

${ }^{15}$ See, e.g., William M. Richman \& William L. Reynolds, Understanding Conflict of Laws $\$ 1$, at 1 (3d ed. 2002); Eugene F. Scoles, Peter Hay, Patrick J. Borchers \& Symeon C. Symeonides, Conflict of Laws $\$ 1.3$ (3d ed. 2000).

${ }^{16}$ Kevin M. Clermont \& Theodore Eisenberg, Exorcising the Evil of ForumShopping, 80 Cornell L. Rev. 1507, 1508 (1995). Compare J. Skelley Wright, The Federal Courts and the Nature and Quality of State Law, 13 Wayne L. Rev. 317, 333 (1967) (deploring that forum-shopping has become "a national legal pastime"); with Friedrich K. Juenger, Forum Shopping, Domestic and International, 63 Tul. L. Rev. 553 (1989) (stressing benefits of forum-shopping); and Mary Garvey Algero, In Defense of Forum Shopping: A Realistic Look at Selecting a Venue, 78 Neb. L. Rev. 79 (1999)

${ }^{17}$ See David W. Robertson \& Paula K. Speck, Access to State Courts in Transnational Personal Injury Cases: Forum Non Conveniens and Antisuit Injunctions, 68 Tex. L. Rev. 937, 938 (1990) ("The battle over where the litigation occurs is typically the hardest fought and most important issue in a transnational case ."). 
who is drafting contracts with an eye toward possible future litigation. Not surprising, then, there exist entire treatises devoted to the subject. ${ }^{18}$ Once in litigation, the parties frequently dispute forum. Courts deal with nearly as many transfer-of-venue motions forum. Courts deal with nearly as many concern of the legal system as trials. ${ }^{19}$ Forum selection is a critical concern of the legal system Accordingly, the U.S. Supreme Court's decisions exhibit the same emphases: jurisdiction comes first in importance, and then recogniemphand jurforcement of judgments follow in an orderly fashion tion and enforcement of judgments follow in an orderly fashion, with choice of law entering the Court's mind only as an afterthought. This pattern prompted Linda Silberman's oft-quoted quip ridiculing the court's obsessive concern with jurisdictional limits, in contrast the choice of law. to its negect of critical questions sucts a belief "that an accused is She said that the court's focus reflects a belief than whether."20

more concerned with where he will be hanged than whether.

International experience is not very different from our internal experience. The history of procedural treaty-making in Community Europe had shown an emphasis on jurisdiction, judg ments, and judicial cooperation, rather than on any genera ments, and judicial co of law or civil procedure. ${ }^{21}$ Moreover, in the harmonization of choice of law or ilateral judgments convention at recent attempts to forge a multilateral judgments conve United The Hague, the intense disputes between Europe and the Uniose States focused almost entirely on jurisdiction. ${ }^{22}$ Indeed, those decade-long negotiations aiming at a general convention hung up on national differences over the appropriate jurisdictional provisions, although other formidable roadblocks to success existed as well. ${ }^{23}$

I submit that these tendencies to stress jurisdiction-on the part

${ }^{18}$ Robert C. Casad, Jurisdiction and Forum Selection (2d ed. 1999); Andrew S. (2003).

${ }^{19}$ See Kevin M. Clermont \& Theodore Eisenberg, Exorcising the Evil of ForumShopping, 80 Cornell L. Rev. 1507, 1509 \& n.3 (1995).

${ }^{20}$ Linda J. Silberman, Shaffer v. Heitner: The End of an Era, 53 N.Y.U. L. Rev. 33, 88 (1978)

${ }^{21}$ See Samuel P. Baumgartner, The Proposed Hague Convention on Jurisdiction and Foreign Judgments, 47-67 (2003).

${ }^{22}$ See Samuel P. Baumgartner, The Proposed Hague Convention on Jurisdic-

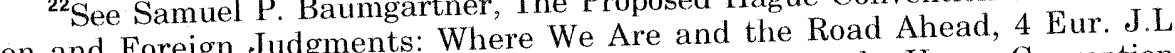
tion and 219 (2002); Kevin M. Clermont, An Introduction to the Hague Convention, Reform 219 (2002); Kevin M. Corm Judgments: Lessons from The Hague 3 (John in A Global Law of Jurisdiction and Judgments. Kevin M. Clermont, Jurisdictional J. Barceló III \& Kevin M. Treaty, 85 Cornell L. Rev. 89 (1999).

Salvation and the Hague Treaty, 85 Cornell L. Rev. 89 (1999).

${ }^{23}$ See Arthur Taylor von Mehren, Theory and Practice of Adjudicatory Authority in Private International Law: A Comparative Study of the Doctrine, Policies and Practices of Conion which (2002). For the latest suggestion of the content in business-to-business contracts, would treat exclusive choice-of-cour agen. Jan. 19, 2004, at 14 see Peter D. Trooboff, Choice-of-Court Clauses, Nat'l L.J., Jan. 19, 2004, at 14 of teachers, lawyers, courts, and negotiators, respectively-are not irrational at all. In several senses, jurisdiction is the queen of private international law doctrines. It deserves this emphasis. It is a place to begin seeking "cooperative development of private international law and international private law." It is a place to begin not only because its importance in practice and theory pleads for international agreement but, also, because apparent national differences suggest that it will prove to be a sticking point in any negotiations.

\section{Importance of jurisdiction in practice and theory}

What is the actual effect of forum selection on the outcome of cases? Practitioners and policymakers share an obvious interest in this question.

\section{A. Forum really affects outcome}

Ted Eisenberg and I have previously used empirical methods to investigate the effect of forum in the context of removal from state to federal court ${ }^{24}$ and in the context of transfer of venue between federal district courts. ${ }^{25}$ Utilizing a database of the three million civil cases terminated in the federal district courts over recent years, the research shows that plaintiffs win much more often when they get to choose the forum. ${ }^{26}$ Forum matters.

Let us define "win rate" as the fraction of plaintiff wins among all judgments for either plaintiff or defendant. Our removal article shows that plaintiffs' win rate in removed cases is very low, compared to original cases in federal court and to state cases. For

Hague Delegates Find Consensus, Narrow Disputes, As Diplomatic Conference Nears, 72 U.S.L.W. 2689 (2004).

${ }^{24}$ Kevin M. Clermont \& Theodore Eisenberg, Do Case Outcomes Really Reveal Anything About the Legal System? Win Rates and Removal Jurisdiction, 83 Cornell L. Rev. 581 (1998) (discussing removal under 28 U.S.C.A. \$ 1441).

${ }^{25}$ Kevin M. Clermont \& Theodore Eisenberg, Exorcising the Evil of ForumShopping, 80 Cornell L. Rev. 1507 (1995) (discussing transfer under 28 U.S.C.A. $\S 1404(\mathrm{a})$, which provides: "For the convenience of parties and witnesses, in the interest of justice, a district court may transfer any civil action to any other district or division where it might have been brought."); see also Kevin M. Clermont \& Theodore Eisenberg, Simplifying the Choice of Forum: A Reply, 75 Wash. U. L.Q. 1551 (1997).

${ }^{26}$ For easy access to part of this database - gathered by the Administrative office of the U.S. Courts, assembled by the Federal Judicial Center, and disseminated by the Inter-university Consortium for Political and Social Research-see Theodore Eisenberg \& Kevin M. Clermont, Judicial Statistical Inquiry Form, at http://teddy. law.cornell.edu:8090/questata.htm, discussed in Theodore Eisenberg \& Kevin M. Clermont, Courts in Cyberspace, 46 J. Legal Educ. 94 (1996); see also Kevin M. Clermont \& Theodore Eisenberg, Litigation Realities, 88 Cornell L. Rev. 119 (2002) (summarizing the range of such empirical research). 
example, the win rate in original diversity cases is $71 \%$ but for removed diversity cases only $34 \%$

The explanation could be the ready one based on the purpose of removal. The defendants thereby defeat the plaintiffs' forum inconveniences, court quality, and advantage and shift the biases, inconveniences, court quality, and procedural law (but not substantive law) in the defendants favor Alternatively, the explanation might lie not in forum impact but " causes us to be comparing two ininstead, Admittedly, removed cases are somecom non-removed cases. Perhaps, the group cases that are hard to win of removed cases might simply explaining the drop in win rate; that (1) out-of-state defendants who be a set of weak cases involving: (1) out-of-state defendants who have satisfied or settled all but plaintiffs' weakest cases, or (2) plaintiff attorneys who have already demonstrated their incompepor is the explanation forum impact or is it case selection?

The offect of a dropping win rate after removal prevails fifferent substantive types of cases, which across the range of different substantive types of cases, Moreargues against the drop being a mere case-selection effect. More over, to isolate the effect on outcome of removal all by its. can use the mathematical technique of regression, which is a statistical tool that helps in choosing the non-removed cases most cases under study and, thus, in comparable in kind to the removed cases under study and analysis neutralizing the case-selection eflect. along with some case indicates that forum impact is at work, along with someriablesselection. After a regression controlling for many case variablessuch as circuit, year, case category, amount demanded, procedural development at termination, method of disposition, and kind of subject-matter jurisdiction-the impact of removal remains sizable and significant. The analysis indicates a residual effect of removal ll by itself that would reduce $50 \%$ odds of a plaintiff"s win to about This $11 \%$ reduction from hypothetically $39 \%$ in diversity cases. impact of the changed forum on the caseeven odds represt. In brief forum really does affect outcome, with the removal effect. In brief, for

removal taking the defendant the win rate drops

We also studied the transfer effect, whereby the win feral civil markedly after transfer of venue. Plaintiffs' win rate in federal civil cases drops from 58\% in cases in which there is no transfer to $29 \%$ in transferred cases.

Xenophilia in American (1996). Multivariate regression is a Courts, 109 Harv. L. Rev. 1120, 1129-1132 (1996) statistical technique that quantifies the influence of (dependent variable). See pendent variables) on the phenomenon being studied (depend Lawyers chs. 13 \& generally Michael O. Finkelstein \& Bruce Levin, Statisties legal issues).
For the transfer effect, the loss of a favorable forum seems to be the primary explanation, because we were able more easily to discount explanations based on differences in the strength of non transferred and transferred cases. That is, the win rate declines largely because the plaintiff has lost a forum advantage. A plaintiff's odds would drop after transfer of venue from $50 \%$ to $40 \%$ after con trolling for all available variables. ${ }^{28}$ Neither the court system nor the applicable law changes after transfer, so we must be seeing only the effects of a strongly shifted balance of inconveniences and a shift of local biases. Still, such a big effect of transfer in reducing the win rate is not surprising. Transferred cases comprise those cases where the forum advantage would be the greatest. After all the plaintiff tried to forum-shop, the defendant chose to fight back and the court, in granting transfer, decided that the forum really mattered. The transferred plaintiffs all lost a big forum advantage and, thus, litigated less successfully in the unfavorable forum, so the win rate dropped.

A normative lesson emerges here too. Given the nature of transfer, the transferee forum is usually a more just forum, giving a more accurate outcome. Under the governing statute's terms, transfer undoes the plaintiff's forum advantage only when the "interest of justice" so counsels and, therefore, undoes the plaintiff"s opportunity to gain an unjust victory in litigation (or to achieve an unjust settlement-our research showed the effect of transfer seen in judgments carries over to influence all non-judgment settlements and other resolutions). Transfer works to neutralize any lopsided cost advantage, and thereby to equalize the effectiveness of the two sides' litigation expenditures, so the outcome should also be more accurate in the transferee court. Note that transfer does not shift the choice of forum from plaintiff to defendant but, instead, from plaintiff to judge. Moreover, the judge decides to transfer only in rather extreme cases of forum-shopping, normally respecting the presumption in favor of the plaintiff's selected forum. In short, the transferee forum should generally be a better forum affording a better outcome.

Therefore, the transfer study shows that forum matters, in terms of both outcome and justice. Accordingly, plaintiffs frequently choose the initial forum to obtain an advantage-if only to sue at home, as they often do. Transfer offsets the advantage, but transfer occurs in only $1 \%$ to $2 \%$ of federal civil cases. So some plaintiffs still are managing to forum-shop their way to unjust victories. A role consequently remains for a robust federal law of territorial author-

${ }^{28}$ Compare Kevin M. Clermont \& Theodore Eisenberg, Do Case Outcomes Really Reveal Anything About the Legal System? Win Rates and Removal Jurisdiction, 83 Cornell L. Rev. 581, 603 n. 67 (1998) (showing reduction to $38 \%$ for diversity cases alone). 
ity to adjudicate, one that ensures the plaintiff is choosing initially from a limited list of fair forums.

In summary, study of removal and transfer suggests a consistent forum effect, whereby the plaintiff's loss of forum advantage by removal or transfer reduces its chance of winning by about one-fifth. ${ }^{29}$ I do not maintain that this insight from empirical research is surprising, because in the main it confirms what most lawyers already knew. The name of the game indeed is forum-shopping, and so all those lawyers out there are in fact not wasting their clients' money on forum fights:

Choice of forum can mean joyous victory or depressing defeat. A Che wrong seling law, available remedies, courtroom procedures, and juror prevailing law, avall as quality and character of judges and also attitudes [as well as quality and character of judges and also geographic convenience and cost considerationsl are inimical to your gent you." 30

Likewise, for this and many other reasons, teachers cannot be faulted for giving the subject undue attention.

Some academics, however, have argued that the forum should not matter so much to practitioners. "The notion that either party will be unable to defend or pursue in a distant forum in the vast majority of interstate cases . . . ignores the realities of civil litigation." At the least, say other commentators, the courts themselves should worry less about territorial authority to adjudicate. Because no fundamental liberty interest is at stake, society would be better off it just abandoned the restraints of law on forum and let courts discretionarily decide whether to entertain a non-local case; all that law on territorial authority to adjudicate, then, "is really a solution

${ }^{29}$ This empirical result is working its way into further research. For example, ${ }^{29}$ This empirical result is work an article of the doctrinal variety, in which the auth this forum-shopping, builds on prevailing forum-selection doctrines that permit all Antony L. Ryan, Principles of the established premise of a sizable forum effect. Antony Forum Selection, 103 W. Va. L. Rev. 167, 168, 200 (2000). Anforcement in the undertook the first large-scale empirical analysis of patent enforcement in the federal district courts. Kimberly A. Moore, Forum Shopping in Patent Cases: Does federation?, 79 N.C. L. Rev. 889, 901 n.50, 920 n.99 Geographic Choice Aft that a wide choice of forum exists in patent litigation, that (2001). She concluded that a we forum continues to play the parties actively work to select the forum, antion. "Forum shopping is alive and a critical role in the outcome of patent litigation. "Forum Shopping in Patent Cases: well in patent litigation." Kimberly A. Moore, Forum . Rev. 889, 937 (2001).

Does Geographic Choice Affect Innovation?, 79 N.C. L. Rev. 889, 937 (1998).

${ }^{30}$ Gita F. Rothschild, Forum Shopping, 24 No. 3 Litig. 40, 40 (1998).

${ }^{31}$ Patrick J. Borchers, The Death of the Constitutional Law of Personal Jurisdiction: From Pennoyer to Burnham and Back Again, 24 U.C. Davis L. Rev. $19,95(1990)$. in search of a problem."32 I disagree. The choice of forum has a tremendous impact on the chance of winning and, hence, on the value of settlement, and at least the practitioners know this. Basic fairness is at stake, and accordingly lawmakers should worry about the law of territorial authority to adjudicate.

Here comes the significant observation. All of the foregoing discussion on the importance of forum concerned litigation within the United States. Consider now international litigation. The choice of forum becomes much more important. Shifting inconveniences and changing biases from one forum to a foreign forum become staggeringly effective. ${ }^{33}$ Moreover, the differences in substantive and procedural law - as well as the matters of remedies and expensesdwarf the small variations within American law. What is the forum's law on antitrust, will there be a jury, how big will the damages be fixed and will they be trebled, can the plaintiff's lawyer proceed on a contingent fee, and will the loser have to pay the winner's expenses? Because of all these differences, international litigators and the various national legal systems really need to worry about the law of territorial authority to adjudicate-the law on where a plaintiff can demand a defendant's "hanging."

\section{B. Jurisdictional harmonization remains \\ desirable}

When thinking of jurisdiction, one tends to think mainly in terms of the difference in law that turns on selected forum but as the removal and transfer studies show, cultural and institutional differences have a huge impact too. Consider three aspects of each of the cultural, institutional, and legal sets of differences:

(1) cultural differences:

(a) the inconveniences of distant litigation will never drop to zero;

(b) local biases will always remain at play; and

(c) the particular social context, including language and culture, will inevitably affect litigation;

(2) institutional differences:

(a) the realm of social ordering that is given over to litigation differs widely from country to country;

(b) courts show great differences in nature and quality; and

${ }^{32}$ Wendy Collins Perdue, Personal Jurisdiction and the Beetle in the Box, 32 B.C. L. Rev. 529, 530 (1991).

${ }^{33}$ See Kimberly A. Moore, Xenophobia in American Courts, 97 Nw. U. L. Rev. 1497, 1499-501 (2003) (stressing ethnocentric biases); Utpal Bhattacharya, Neal Galpin \& Bruce Haslem, The Home Court Advantage in International Corporate Litigation (Feb. 2004) (manuscript on file with author); compare Kevin M. Clermont \& Theodore Eisenberg, Xenophilia in American Courts, 109 Harv. L. Rev. 1120 (1996) (showing a strong case-selection effect in data from 1986-1994). 
(c) lawyers' roles, and the expense and funding of litigation, likewise differ greatly;

(3) legal sets of differences:

(a) procedural law varies in surprisingly deep and contentious ways,

(b) substantive law, of course, still exhibits wide variation; and

(c) choice-of-law doctrines, as applied, fail to eliminate differences in governing law.

this list means is that where a case is heard is very important. at in ace in appropriate It is critical to ensure the cases in a way so that all can accept forum, that is, to divs dispute.

The reformist goal of jurisdictional regulation and harmonization

The refoditional ideal of private international law:

en law in general; on the contrary, this lts aim is not the uniform system is the modus vivendi by which purety tistics can exist side by all their peculiarities and national characteristics canunicipal courts side. The ideal, to which it is working is that no two mun to pive differthe systems of law which they apply, to give differ shall be forced, by the achieve such an ideal it ent judgments on the same state of facts. To achiev of law of different is not necessary that the purely territorial systems of law merely that countries shall approximate to each other in any way, but same.

their systems of Private International Law shall be the same.

Private International Law, properly conceived, never directly creates legal rights or liabilities: that is the function of the purely territorial branches of law. Hence, it is not like the latter, a creation to the national consciousness which in its development must be free to follow the national genius. It can, therefore, much more easily be

moulded in sympathy with external thought and non-jurisdictional aspects It turns out that reaching al not all that

of private international law is not all that easy:

Universal conventions regulating choice of law have had. "decisional impact in reducing the potential for for um shopplaw theory, espeharmony," which traditionally private international law theory ensurcially in Continental Europe, thought would end the practice by ensurcially in Contin in the applicable substantive rules, has proved to be a ing uniformity in the applicable substantive choice-of-law rules, the mirage. If all forums actually applied the same choice-of-law would be advantage enjoyed by the party that selects the In all events, as a reduced, though by no means entirely eliminated. In all eventsersal reduced, though by achieving decisional harmony through universal new century dawns, achieving dating choice of law seems even more international conventions regulating choice of.$^{35}$

elusive than when the twentieth century began.

This roadblock

${ }^{34} \mathrm{~W} E$ Beckett, What Is Private International Law?, 7 Brit. Y.B. Int'l L. 73, 95-96 (1926).

${ }^{35}$ Arthur Taylor von Mehren, Theory and Practice of Adjudicatory Authority in Private International Law: A Comparative Study of the Doctrine, Policies and regulation and harmonization. My belief is not that a more modest focus on jurisdiction makes reform easy. ${ }^{36}$ But within private international law, jurisdiction still may be the path of least resistance to reform.

In this great need for and relative feasibility of jurisdictional reform lies the defensible reason that the U.S. Supreme Court and international negotiators have focused so much attention on the subject. Moreover, jurisdiction could be the key that unlocks the door to a better world order and justice. Given agreement on territorial jurisdiction, coordination regarding recognition and enforcement of the resultant judgments is readily achievable. Even agreements on judicial cooperation on service and evidence become more likely once countries are assured that only courts exercising appropriate jurisdiction can request such assistance.

I do concede that even feasible reform occurs only when truly need-driven, no matter how much academics desire and preach reform. I contend that public and private needs for jurisdictional reform (and not just in specialized areas) are very real. The failure to recognize these needs - not the absence of needs-has resulted in the current dearth of treaties on the subject, as well as in the lack of federalization of the law in the United States.

\section{Non-jurisdictional harmonization remains unlikely}

The reader who did not buy into the above-quoted idea of fostering "the national genius" might still be struggling with this nagging question: Why pursue a jurisdictional agreement, which will not be easy to reach, rather than follow the alternative and more direct path of harmonizing the laws of different nations? Indeed, Article 65(b) \& (c) of the Treaty Establishing the European Community may envisage harmonizing the choice-of-law rules or civil-procedure systems of the member states. ${ }^{37}$ More widely, we could seek to harmonize laws across the European Union and U.S. procedural systems, whether for the possible efficiency of similarity when national judiciaries interact, for actual improvements within various nations' procedure, or even for complete effectuation of

Practices of Common- and Civil-Law Systems, 295 Recueil des cours 9, 312 (2002) (footnote omitted).

${ }^{36}$ Compare Evan Tsen Lee, The Dubious Concept of Jurisdiction, 54 Hastings L.J. 1613 (2003) (arguing that jurisdiction is not inherently different from the merits).

${ }^{37}$ Compare Paul R. Beaumont, Private International Law of the European Union, this volume (taking a narrow view of art. 65) 
harmonized substantive law. ${ }^{38}$ Such harmonization could come either by voluntary borrowing of transplants ${ }^{39}$ or by mutual agreement between systems. ${ }^{40}$ Let us consider these two routes.

First, actual transplanting-as opposed to the mere seeking of inspiration abroad for locally generated reform-is not common within the realm of procedure. ${ }^{41}$ Transplants that impinge on the system's organizing principles or constitutional norms are obviously impractical ${ }^{42}$ but even less intrusive transplants of foreign devices are problematic. ${ }^{43}$ The reason is that procedure is a field especially marked by the interrelatedness of its parts and its inseparability from the local institutional structure. ${ }^{44}$ Also, although it is a techni-

${ }^{38}$ See generally Kevin M. Clermont, Foreword: Why Comparative Civil Procedure?, in Kuo-Chang Huang, Introducing Discovery into Civil Law at ix (2003).

${ }^{39}$ See Alan Watson, Legal Transplants: An Approach to Comparative Law 21 30, 95-101, 107-118 (2d ed. 1993). But see Pierre Legrand, The Impossibility of "Legal Transplants," 4 Maastricht J. Eur. \& Comp. L. 111 (1997); Alan Watson, Legal Transplants and European Private Law, in The Contribution of Mixed Legal Systems to European Private Law 15 (Jan Smits ed., 2001) (responding to Legrand).

${ }^{40}$ See Konstantinos D. Kerameus, Procedural Unification: The Need and the Limitations, in International Perspectives on Civil Justice 47 (I.R. Scott ed., 1990)

${ }^{41}$ See George A. Bermann, The Discipline of Comparative Law in the United States, in L'avenir du droit comparé 305, 307 (Société de Législation Comparée 2000); John A. Jolowicz, On the Comparison of Procedures, in Law and Justice in a Multistate World 721, 724-725 (James A.R. Nafziger \& Simeon C. Symeonides eds., 2002).

${ }^{42}$ See Stephen Goldstein, The Proposed ALI/UNIDROIT Principles and Rules of Transnational Civil Procedure: The Utility of Such a Harmonization Project, 6 Uniform L. Rev. (n.s.) 789, 791, 793-794 (2001).

${ }^{43}$ See Benjamin Kaplan, Civil Procedure-Reflections on the Comparison of Systems, 9 Buff. L. Rev. 409, 422 (1960):

Possibilities of lifting pieces from a foreign system and incorporating them in the domestic must be approached with a sense of the interdependencies, the syndromes, so to speak, within the system a quo and the system ad quem. This is not to say that it is no use trying to import mechanisms for domestic use unless the foreign system is brought over entire. For some procedural devices can stand up pretty well in isolation from the rest of the system. I put as possible examples the special "dunning" and documentary processes successfully employed in many cases in Germany. . . . Consider the feasibility of introducing here the German practice of having witnesses give their testimony in narrative, followed by interrogation by the court; this to be followed in turn by interrogation in our conventional way by counsel for both sides. This may seem a simple change that could be commended on various imaginable grounds, but I would ask you to reflect on whether it could be effectively or safely engrafted on our present system without other profound changes.

See also Konstanze Plett, Civil Justice and Its Reform in West Germany and the United States, 13 Just. Sys. J, 186 (1989); John C. Reitz, Why We Probably Cannot Adopt the German Advantage in Civil Procedure, 75 Iowa L. Rev. 987 (1990).

${ }^{44}$ See Mirjan Damaska, The Uncertain Fate of Evidentiary Transplants: Anglo-American and Continental Experiments, 45 Am. J. Comp. L. 839 (1997); John H. Langbein. The Influence of Comparative Procedure in the United States, 43 Am. J. Comp. L. 545, 551-553 (1995). cal subject, procedure is surprisingly culture-bound, subtly reflecting the fundamental values, sensibilities, and beliefs of the society. ${ }^{45}$

All this is not to say that transplants are impossible. ${ }^{46}$ Indeed, I have elsewhere suggested for the United States a procedural transplant within the realm of lis pendens. ${ }^{47}$ Such transplants normally must be limited in scope and sensitive to context. Take discovery as an example. Comparative study of discovery unsurprisingly reveals practices to be quite variable. ${ }^{48}$ Perhaps better approaches and devices exist in other countries, ripe for transplanting. However, discovery schemes are highly interdependent with the rest of the procedural system-think of how discovery in the U.S. federal system interplays with notice pleading and with downplayed trialand with the professional setting-think of how discovery links to the lawyers' and judges' ethos. Moreover, discovery peculiarities tend to be more culture-bound than most of procedure-think of the emotions that discovery evokes on both sides of the Atlantic. Therefore, in ordinary times, discovery does not provide promising terrain for nurturing transplants, or at least transplants other than the most delimited procedures drawn from the most similar systems.

Second, we should consider harmonization of procedure by international agreement. Such harmonization is no easier than transplanting, and so it too is little done. ${ }^{49}$ Indeed, the need for agreement among multiple countries joins all the impediments to

${ }^{45}$ See Oscar G. Chase, American "Exceptionalism" and Comparative Procedure, 50 Am. J. Comp. L. 277 (2002).

${ }^{46}$ See Stephen Goldstein, The Odd Couple: Common Law Procedure and Civilian Substantive Law, 78 Tul. L. Rev. 291 (2003) (examining mixed jurisdictions) John A. Jolowicz, On the Comparison of Procedures, in Law and Justice in a Multistate World 721, 722-724 (James A.R. Nafziger \& Simeon C. Symeonides eds. 2002) (discussing, inter alia, Greek and Japanese procedure); Andreas F. Lowenfeld, Introduction: The Elements of Procedure: Are They Separately Portable?, 45 Am. J. Comp. L. 649 (1997)

${ }^{47}$ Kevin M. Clermont \& Kuo-Chang Huang, Converting the Draft Hague Treaty into Domestic Jurisdictional Law, in A Global Law of Jurisdiction and Judgments: Lessons from The Hague 191, 226-228 (John J. Barceló III \& Kevin M. Clermont eds., 2002) (arguing for U.S. adoption of European lis pendens doctrine). See ALI, International Jurisdiction and Judgments Project $\$ 11$ (Tentative Draft 2004) (presenting a similar proposal). See, e.g., Stephan Landsman, Reforming Adversary Procedure: A Proposal Concerning the Psychology of Memory and the Testimony of Disinterested Witnesses, 45 U. Pitt. L. Rev. 547 (1984) (arguing for U.S. adoption of Germanic restriction on attorneys' pretrial contacts with witnesses). $1990)$.

${ }^{48}$ See Pre-Trial and Pre-Hearing Procedures Worldwide (Charles Platto ed.

${ }^{49}$ See George A. Bermann, The Discipline of Comparative Law in the United States, in L'avenir du droit comparé 305, 307 (Société de Législation Comparée 2000); John A. Jolowicz, On the Comparison of Procedures, in Law and Justice in Multistate World 721, 725-726 (James A.R. Nafziger \& Simeon C. Symeonides eds., 2002). 
transplants ${ }^{50}$ On the one hand, the need for agreement may require the best procedure, something in the a compromise away from the best procedure, something in the middle not always being an optimum. Such compromises would reduce the benefits of harmonization. On the other hand, some rece susceptible to compromise, as a device like jury trial or does not, and whould affect the countries' willingness to this more binary choice would affect the within them, turn out to be agree. Countries, and vested interests within them, remarkably devoted to their procedural traditions.

Tarmonization by agreement is nonetheless sometimes worth 列 pecially promising areas of judicial cooperation, foreign judgments,

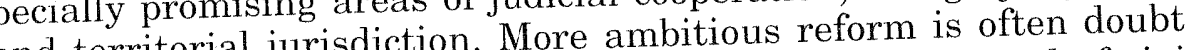
and territorial jurisdiction. procedure. The difficulties best appear through two examples.

The most prominent example of attempted harmonization cur rently is the ALI/UNIDROIT project on transnational civil (52 It aim was to produce a complete set of court rules procedure. Its aim disputes, that a nation the civilaw and arbitration. Proceeding on a view that thities but display common-law traditions share fundamental similarities but display methodological differences, the reporters set out to capture the best of both traditions by picking and choosing elements from each. In of both thaditions aim is ambitious and especially when the method entails cutting-and-pasting. and especially when the mat there is a Initially, and arguably wrongly, the project assumes that is, to more than best set of procedures applicable bricular society. Moreover, and certain kinds of litigation in one particular society. Moreover, and inevitably, a complete set of new rules impinges on sometrue basics of the various nations' procedural systems, while cutting-andpasting ignores some of the interdependencies of procedure. Finally, such an unavoidably value-laden and subjective endeavor becomes an ill-advised one in the virtually total absence of empirical evidence.

Although the ALI project has proceeded under the direction of Althed reporters, their experience to date has seemed to prove the difficulties of harmonization. The drafting process has been contro-

${ }^{50}$ Compare James Gordley, Comparative Legal Research: Its Function in the (arguing for harDevelopment of Harnonized Law, 43 Am.

monizing legal science rather than laws).

${ }^{51}$ See John A. Jolowicz, On the Comparison of Procedures, in Law and Justice in a Multistate World 721, 725-727 (James A.R. Nafziger \& Simeon C. Symeonides eds., 2002 (beroamerica).

${ }^{52} \mathrm{ALI} / \mathrm{UNIDROIT}$ Principles and Rules of Transnational Civil Procedure (Proposed Final Draft 2004). versial since its inception in the mid-1990s, with criticisms coming from all directions, and the project has consequently experienced a constant narrowing of scope. It now covers only commercial transactions, while deferring more to national laws. As to the project's future, this responsiveness of the reporters shows promise. On the one hand, the rules still seem a suboptimal melange that few countries will willingly embrace. If any did, the new rules would sit uncomfortably atop the different national procedural system for ordinary cases. On the other hand, the project now will state general principles in addition to the rules. A set of principles would be more feasible in terms of achieving agreement, because principles need not be so complete and are less binding and more abstractyet they could be effective in eventually inducing changes in national rules. ${ }^{53}$

The European Union has provided another example that shows the difficulties of procedural harmonization. ${ }^{54}$ Its most thoroughgoing effort to date involved a working group of 12 experts from 1987 to 1993. They started by expressing an aim to create a European

${ }^{53}$ See Stephen Goldstein, The Proposed ALI/UNIDROIT Principles and Rules of Transnational Civil Procedure: The Utility of Such a Harmonization Project, 6 Uniform L. Rev. (n.s.) 789, 795-801 (2001); John A. Jolowicz, On the Comparison of Procedures, in Law and Justice in a Multistate World 721, 730-731, 733-734 (James A.R. Nafziger \& Simeon C. Symeonides eds., 2002). Some contend that the ALI/UNIDROIT project leans too much toward common-law approaches. See Stephen Goldstein, The Proposed ALI/UNIDROIT Principles and Rules of Transnational Civil Procedure: The Utility of Such a Harmonization Project, 6 Uniform L Rev. (n.s.) 789, 796 (2001); John A. Jolowica On the Comparison of Procedurn in. Symeonides eds., 2002). But the pr Symeonides eds., 2002). But the project, for example, rejects American-style discovery on the valid assumption that such procedures would be unacceptable elsewhere in the world. It states instead this principle: "Upon timely request of a party, the court should order disclosure of relevant, non-privileged, and reasonably identified evidence in the possession or control of another party or, if necessary and just, of a nonparty. It is not a basis of objection to such disclosure that the evidenee may be advers UNIDROIT Principles and Rules of Transnational Civil Procedure (Proposed Final Draft 2004), principle 16.2. In its rules, however, the project does not provide for routine "disclosure" of adverse information, but instead allows a party to request the court to order production of non-confidential and non-privileged documents that are specifically identified and directly relevant to the pleaded issues in the case. See ALI/UNIDROIT Principles and Rules of Transnational Civil Procedure (Proposed Final Draft 2004), rule 22 (providing also that the court can order proALI/UNIDROIT Pring Find Final Draft 2004), rule 23 (limited depositions of witnesses). Its grudging approach, then, is basically this: "A party generally must show its own cards, so to speak, rather than getting them from an opponent." ALI/UNIDROIT Principles and Rules of Transnational Civil Procedure (Proposed Final Draft 2004), at 11

${ }^{54}$ See Stephen Goldstein, The Proposed ALI/UNIDROIT Principles and Rules of Transnational Civil Procedure: The Utility of Such a Harmonization Project, 6 Uniform L. Rev. (n.s.) 789, 791-792 (2001); John A. Jolowicz, On the Comparison 
code of civil procedure, but finished by producing a report that con a small number of discrete topics. ${ }^{55}$ Although never implemented, the draft rules were well reasoned Although never implemented, the rules are limited in scope and leave much to national law. Their harmonization focuses on the most pressing points of procedural friction between systemsmost pressing point that involve non-systemic and independent points, additionally,

These two examples suggest that wide-ranging procedural These twion is far off in the future. I would go further by arguing harmonization is far off in the even be undesirable, as different that broad haflect different values that should not be disregarded. In any event, and this is the significant point here, even if procedural transplantem. Alignment of non-jurisdictional laws, would not solv the mould not affect some of the mons we even of choice of law, would not affect some of the worry about jurisdiction: biases, inconveniences, and the other nonlegal differences between forums. Jurisdiction should therefore remain the principal focus of harmonization for the foreseeable future.

\section{Transatlantic differences on jurisdiction}

Although harmonization of non-jurisdictional law remains quite Alikely, jurisdictional harmonization becomes increasingly feasible because U.S. jurisdictional law in fact exhibits no essential differences from European Union law and because the significant differences that do exist are decreasing with time.

\section{A. Summarizing U.S. law}

A quick summary of the U.S. law on jurisdiction is necessary to

Procedures, in Law and Justice in a Multistate World 721, 727-729 (James A.R Nafziger \& Simeon C. Symeonides eds.,2002).

${ }^{55}$ Approximation of Judiciary Law in the European Union (Marcel Storme ed., 1994).

${ }^{56}$ See Stephen Goldstein, The Proposed ALI/UNIDROIT Principles and Rules of Transnational Civil Procedure: The Utility of Such a Harmonization Project, 6 Uniform L. Rev. (n.s.) 789, 792 (2001). Compare Konstantinos D. Kerameus, PolitUniform L. Rev. (n.s.) 789, 792 (2001). Compare in the European Union, 45 Am. J. ical Integration and Procedural Convergence in the European Union, 45 Am. J. Comp. L. 919, 924-929 (1997) (justifying limited approach), with Friedrich K. Juenger, Some Comments on European Procedural Harmonization, $45 \mathrm{Am}$. Comple com would have introduced to the of discover discovery of Continent a form documents. See Approximation of Judiciary Law in the Eurt 4). They would have 172-173, 195-198 (Marcel Storme ed., 1994) (discussing art. 4). They would have required a party to list all relevant documents in its possession, custody, or power. They would also have allowed a litigant to obtain non-privileged documents from parties and nonparties, unless such discovery would cause undue harm. support my point. I begin by admitting that U.S. jurisdictional law has the reputation of being overreaching, vague, and complicated, and that this reputation may be deserved to a certain extent. Closer examination reveals, however, that the essence of the U.S. law is quite defensible-and should be quite understandable to Europeans. ${ }^{57}$

For a court to properly undertake a civil adjudication, the court must have territorial authority to adjudicate. This requirement confines the place of litigation, putting restrictions on the court's authority to entertain litigation with non-local elements. The basic U.S. law on the subject is this: the forum acquires adjudicatory authority in civil cases through power over the target of the action (be it a person or a thing), unless litigating the action there is unreasonable (that is, fundamentally unfair) - although the sovereign naturally can choose self-restraint (exercising less than its full adjudicatory authority under the Constitution).

The U.S. Supreme Court has formulated these principal limitations on a court's territorial authority from the opaque few words of the due process clauses of the U.S. Constitution. ${ }^{58}$ It has largely elaborated the U.S. law on the interstate level and, in fact, it has decided only four international cases. ${ }^{59}$ The United States has no general treaties on international jurisdiction.

\section{Power}

Prompted by the tensions among states in a federation of sovereigns, the United States early adopted a theory of exclusive power based on territoriality: each sovereign had jurisdiction, exclusive of all other sovereigns' jurisdiction, to bind persons and

${ }^{57}$ See generally Kevin M. Clermont, Civil Procedure 161-192 (7th ed. 2004); Kevin M. Clermont, Civil Procedure: Territorial Jurisdiction and Venue (1999).

${ }^{58}$ The U.S. Constitution's Fifth and Fourteenth Amendments prohibit the federal and state governments, respectively, from depriving any person of life, liberty, or property "without due process of law." As the U.S. Supreme Court finally made clear in World-Wide Volkswagen Corp. v. Woodson, 444 U.S. $286,100 \mathrm{~S}$. Ct.
$580,62 \mathrm{~L}$. Ed. 2 d 490 (1980), due process dictates both that the forum state must have power over the target of the action and that litigating the action state must be reasonable. The court in Burger King Corp. v. Rudzewicz, 471 U.S. 462, $105 \mathrm{~S}$. Ct. 2174, 85 L. Ed. 2d 528 (1985), further clarified that while the plaintiff has the burden of persuasion as to power, it is up to the defendant to show unreasonableness.

${ }^{59}$ Asahi Metal Industry Co., Ltd. v. Superior Court of California, Solano County, 480 U.S. 102, 107 S. Ct. 1026, 94 L. Ed. 2d 92, Prod. Liab. Rep. (CCH) P 11267 (1987); Helicopteros Nacionales de Colombia, S.A. v. Hall, 466 U.S. 408, 104 S. Ct. 1868, 80 L. Ed. 2d 404 (1984); Perkins v. Benguet Consol Min. Co. 342 U.S. 437, 72 S. Ct. 413, 96 L. Ed. 485, 63 Ohio L. Abs. 146 (1952); compare Omni Capital Intern., Ltd. v. Rudolf Wolff \& Co., Ltd., 484 U.S. 97, 108 S. Ct. 404, 98 I Ed. 2d 415, 9 Fed. R. Serv. 3d 691 (1987) (construing Federal Rules of Civil Procedure's implementation of international jurisdiction). 
things present within its territorial boundaries. This old requirement of power remains very much a part of U.S. law today Henter beyond the basis of However, the scope of power has expanded beyond the basis of physical presence. The common element in specifying the current bases of power - the defining feature of the power test-is the narrow focus on whether the relation of the target of the action to the row focus on whether "minimum contacts," as opposed to a broader sovereign constitutes "minimum contacts," as opposed to a broader inquiry that would take account of the plaintiff's and the public's interests.

This image of power inevitably raised the question of power over what or whom, despite the undeniable fact that all actions really affected the interests of people. That is, to measure the strength of fected the interests of peen the sovereign and the target of the acthe power relation between the sovereign and the target of the action, the law had to specify the target of the action; thus arose the American categorization of territorial jurisdiction into jurisdiction over things and persons. That is, the basic categories of jurisdiction are non-personal and personal jurisdiction:

(1) non-personal jurisdiction, or jurisdiction in rem or quasi in rem, usually involves an action against a thing, or res. Theoretically and often formally, the action is against the thing. No personal liability or obligation results; and ${ }^{60}$

2) personal jurisdiction, or jurisdiction in personam, can result in a judgment imposing a personal liability or obligation upon the defendant in favor of the plaintiff or, more tion upon the defendant in favor of the plaintiff or, morty in favor of another party. This is the most common kind of jurisdiction. For example, a successful tort action resting on personal jurisdiction subjects all of the defendant's nonexempt assets to execution. For another example, a suit for an injunction requires jurisdiction in personam and subjects the defendant to the court's contempt sanctions.

While non-personal jurisdiction still requires physical presence of the thing in order to constitute minimum contacts, personal jurisdiction can now rest on thinner connections. The relationships between the defendant and the forum sufficing to establish power fall into four basic types. These are the primary bases of power for

${ }^{60}$ Non-personal jurisdiction includes the troublesome variety sometimes called attachment jurisdiction, whereby the plaintiff seeks to apply the defendant's propattach to the defendant that is unrelated to the erty to the satisfaction of a claim againtiff might obtain jurisdion in a New property. For example, New York plaintiffs might obtain ju in Turkey simply by York state court for a tort claim arising from a plane crash in Turkey simply by garnishing a New York bank account belonging to the defendant Turkish Airlines. See Feder v. Turkish Airlines, 441 F. Supp. 1273 (S.D. N.Y. 1977). If successful, the plaintiff would apply the bank account to awarded court costs and then to the satisfaction of the tort claim. However, on such attachment jurisdiction, the plaintiff's recovery is limited to the bank account. personal jurisdiction. ${ }^{61}$ Some of these bases of power rest on strong contacts between the defendant and the forum, giving power to adjudicate any personal claim whether or not related to those contacts. It is said that these bases support "general jurisdiction." These bases to establish power workably provide a predictably certain forum, which usually is a fair one:

(1) the ancient basis of presence gives power to adjudicate any personal claim if the defendant is served with process within the sovereign's territorial limits; thus, even momentary presence of the individual creates power-so-called transient jurisdiction - to adjudicate a claim totally unrelated to that presence, ${ }^{62}$ and

(2) the basis of domicile gives power to adjudicate any personal claim if the defendant is domiciled, or incorporated, in the sovereign's territory when served anywhere with process. "The state which accords him privileges and affords protection to him and his property by virtue of his domicile may also exact reciprocal duties." ${ }^{\text {63 }}$

Other bases of power rest on lesser contacts between the defendant and the forum, giving power to adjudicate only those personal claims related to the contacts; thus, these bases support "specific jurisdiction." They provide useful and indeed necessary jurisdiction, but can generate some very difficult problems of line-drawing:

(1) an individual or corporate defendant may actually consent to personal jurisdiction, thereby creating a basis of power defined by the terms of the consent. The possibility of the defendant's limiting the consent justifies classifying the consent basis under the heading of specific jurisdiction. The defendant may express consent in a number of ways. The defendant may consent before suit is brought, such as in the common provision in business contracts consenting to a particular state's jurisdiction, or pursuant to the common statutory requirement that anybody seeking a license to do business in a state must appoint a local agent to accept service of process. Alternatively, the defendant may consent after suit is brought, by accepting or waiving ser-

${ }^{61}$ Of course, to survive due process scrutiny, any exercise of jurisdiction must not fail the more free-form test of unreasonableness. Nevertheless, because of the more restrictive role of the power test, cataloguing the primary bases of power is in fact an expressive means for mapping the bounds on personal jurisdiction.

${ }^{62}$ See, e.g., Grace v. MacArthur, 170 F. Supp. 442 (E.D. Ark. 1959) (valid service on defendant flying over state).

${ }^{63}$ Milliken v. Meyer, 311 U.S. 457, 463, 61 S. Ct. 339, 85 L. Ed. 278, 132 A.L.R. 1357 (1940) 
vice of process, or by choosing not to object to personal jurisdiction; and ${ }^{64}$

(2) a relatively new and very vibrant basis of power gives the state power over an individual or corporation that has committed certain state-directed acts, but the power extends only to those personal claims arising out of those acts. ${ }^{65}$ Important examples include: (a) tortious acts; (b) business activity; (c) property ownership, use, or possession; and (d) litigating acts. These examples should not give the idea that anything goes. The Supreme Court has sometimes found the defendant's activity too slight to bestow power on the state. ${ }^{66}$ Drawing the line is difficult; however phrased, the test in application turns on a close inspection of the facts and circumstances peculiar to the case. The issue of minimum contacts "is one in which few answers will be written in 'black and white. The grays are dominant and even among them the shades are innumerable.' "'67

${ }^{64}$ See National Equipment Rental, Limited v. Szukhent, 375 U.S. 311, 84 S Ct. 411, 11 L. Ed. 2d 354, 7 Fed. R. Serv. 2d 23 (1964).

${ }^{65}$ See International Shoe Co. v. State of Wash., Office of Unemployment Compensation and Placement, 326 U.S. 310,66 S. Ct. 154, 90 L. Ed. 95, 161 A.L.R. 1057 (1945). However, as the level of the defendant's state-directed activity increases, the state's power extends to claims less related to that activity. Both the level of activity and the degree of unrelatedness are continua. If state-directed activities are considerable, they bestow power even though the activities might be coctivition actually "ansidered partial paralle, or inciden "arose from," if those state-directed activities suficiently "relate to" the claim. Indeed, if a defendant's business activities in the forum state when served with process are extensively continuous and systematic-which is phrased as "doing business" rather than merely "transacting business"- the defendant becomes subject to jurisdiction even on claims wholly unrelated to the in-state activities. In this way, the development of jurisdiction based on state-directed acts has brought into the the specific and general into the open the abs. 342 U.S. 437, 72 S. Ct. 413, jurisdiction. See Perkins v. Benguet Consol. Min 96 L. Ed. 485, 63 Ohio L. Abs. 146 (1952) (upholding jurisdiction in an Ohio statecourt suit against a Philippine corporation, which was performing all of its management activities in Ohio while mining was suspended by the effects of war in the Philippines, on a basically unrelated claim); compare Helicopteros Nacionales de Colombia, S.A. v. Hall, 466 U.S. 408, 104 S. Ct. 1868, 80 L. Ed. 2d 404 (1984) (finding ing no general jurisdiction in Texistion).

${ }^{66}$ See, e.g., Kulko v. Superior Court of California In and For City and County of San Francisco, 436 U.S. 84, 92, 98 S. Ct. 1690, 56 L. Ed. 2d 132 (1978) (finding jurisdiction unconstitutional when, after a New York couple divorced and after the wife and two children moved to California, the wife brought a California statewife and two childrill mover to Cark

${ }^{67}$ Kulko v. Superior Court of California In and For City and County of San Francisco, 436 U.S. 84, 92, 98 S. Ct. 1690, 56 L. Ed. 2d 132 (1978) (quoting Estin v. Estin, 334 US. 541, 545, 68 S. Ct. 1213, 92 L. Ed. 1561, 1 A.L.R.2d 1412 (1948))

\section{Unreasonableness and self-restraint}

Another product of the judicial elaboration of due process has been the overlaying of an unreasonableness test onto the power test. The newer test of unreasonableness balances the opposing parties' interests, along with the public's interests in the litigation. It also takes into account a diverse and complete set of relevant considerations, such as the actualities of the choice-of-law process. Although rather uncertain in application, this party-neutral and all-things-considered test directly measures jurisdiction by the pertinent standard of "fair play and substantial justice," that is, the minimal floor of fundamental fairness in the broadest sense. The chosen forum need not be the ideal forum, but the forum, even if it has power, must not be an unreasonable one in light of all these interests in the litigation.

The state and federal sovereigns have, in fact, chosen to exercise less than their full adjudicatory authority under the Constitution. These choices find expression in a variety of statutes and doctrines. Most prominent among them is the law of venue.$^{68}$ Venue, at least as traditionally defined, does not exhaust these subconstitutional restrictions on geographic selection of forum. For an obvious example, forum non conveniens is a doctrine of self-limitation, whereby a court may discretionarily decline existing territorial authority to adjudicate if the court is a seriously inappropriate forum and if a substantially more appropriate forum is available to the plaintiff. Sovereigns have developed other statutes and doctrines that decline, albeit usually in minor ways, constitutionally permissible territorial authority to adjudicate with respect to certain nonlocal cases. For example, a state's statute might close its courthouse doors to any action between nonresidents on a claim arising outside the state. Therefore, all of these self-imposed limitations form part of the law of territorial authority to adjudicate, properly conceived.

Unreasonableness and self-restraint are similar, in theory. The former embodies the most basic aspects of fairness and so the U.S. Supreme Court has forced it on the law by means of constitutional

${ }^{68}$ See text accompanying notes 97-100 \& 113-118 (describing U.S. venue law) Any study of territorial authority to adjudicate would be incomplete without considering the subset of law on venue. Nonetheless, the definition of venue is frustratingly murky. Venue naturally includes so-called venue statutes and doctrines, but it also includes or at least abuts transfer provisions, forum selection clauses, and forum non conveniens, as well as restrictions on serving process and other of the sovereign's self-imposed limitations such as door-closing statutes and lis pendens doctrines. Best defined, venue comprises all the subconstitutional dis pendens doctrines. Best defined, venue comprises all the subconstitutional
doctrines that work to site litigation in particular courts, and presumably appropriate courts, among the several of the sovereign's courts that have constitutional authority-or, conceivably, work to oust them all of authority. See generally Kevin M. Clermont, Restating Territorial Jurisdiction and Venue for State and Federal Courts, 66 Cornell L. Rev. 411 (1981). 
interpretation. The latter restraints are those that the federal and state governments have additionally chosen to adopt as restrictions on themselves.

\section{B. Searching for essential differences}

As long as scholars have studied jurisdiction comparatively, they have tried to encapsulate their findings in terms of an essential difference. They might have concluded that:

(1) the peculiar U.S. jurisdictional law flows inevitably from a different theory of governmental authority, one that rests on power notions;

(2) U.S. law differs because its legal institutions have managed to constitutionalize jurisdiction

(3) it is the same old story of common-law courts playing too active a part in the development of the law in the United States;

(4) the United States has resolved the fundamental jurisprudential tension between certainty and precision in a way that maximizes the role of fact-specific inquiry; or

(5) those activist courts are ironically too willing to decline the jurisdiction bestowed on them by the legislature.

Each of these assertions has some truth in it, as I shall discuss below. Perhaps there exists some other key explanatory difference between common-law and civil-law approaches, to be uncovered by fresh insight. Differences do exist. These differences reveal the path-dependent, or contingent, nature of jurisdictional law: the current law does reflect where it came from. Moreover, the differences rent law does reflect where it came from. Moreover, the differenter conter courts in the United States do play a slightly different role than do courts in Europe. Nevertheless, I contend that none of the differences is essential in the sense of being unbridgeable.

My contention should not shock. After all, for the United States and Europe, jurisdiction presents to similar social systems a similar legal problem-in the identical international context. Each system, despite its somewhat different history and socio-legal context, is despite its somewhat different history and socio-legal context, is heavily on the toes of all other countries-with each system confronting an array of other countries that display the full range of prevailing contexts. Therefore, the systems should come up with answers that are not too far apart and are converging toward the center. The systems should not exhibit essential differences. ${ }^{69}$

Even in the doctrinal details of jurisdictional law, the differences

${ }^{69}$ See Arnaud Nuyts, Due Process and Fair Trial: Jurisdiction in the United States and in Europe Compared, this volume ("it is a common feature in comparative law to observe that similar causes lead to similar effects"). are smaller than they appear in the mirror. Consider exorbitant jurisdiction, where national peculiarities peak. French nationalitybased jurisdiction or German property-based jurisdiction does not look much like U.S. transient jurisdiction, attachment jurisdiction, or doing-business jurisdiction, but in fact they share a common core. "[N]ations tend to give their own people a way to sue at home, at least when the home country will be able to enforce the resulting judgment." ${ }^{\text {To }}$ The unimportance of this jurisdictional filigree is evidenced by the European Union countries' abandonment of their exorbitant jurisdiction for use against domiciliaries of fellow member states, ${ }^{71}$ as well as by the United States' professed willingness to surrender at least its transient and attachment jurisdiction in exchange for a multilateral jurisdiction-and-judgments convention. ${ }^{72}$ I would contend that the United States should become even more open to cutting back its jurisdictional reach, as by giving up doing-business jurisdiction, and thereby diminish its somewhat unwarranted reputation for jurisdictional excess. ${ }^{73}$

\section{Origin in power}

Admittedly, the U.S. jurisdictional doctrine's founding on a power theory is a significant marker. ${ }^{74}$ This origin still affects U.S. law in many ways, although the effects are diluted because the scope of power has expanded so far beyond the original basis of physical presence. Perhaps the origin's most significant enduring effect is the oft-noted, but sometimes exaggerated, American emphasis on the forum's required connection to the defendant, in distinction to

${ }^{70}$ Kevin M. Clermont \& John R.B. Palmer, French Article 14 Jurisdiction, Viewed from the United States, in De tous horizons 473, 475 (Société de Législation Comparée 2005).

${ }^{71}$ See Council Regulation (EC) No. 44/2001 of 22 Dec. 2000, on jurisdiction and the recognition and enforcement of judgments in civil and commercial matters, art. 3, O.J. Eur. Comm. L 012/1, 2000 WL 33114112, 16 Jan. 2001, Appx. D1 (Brussels I Regulation), as amended by Council Regulation (EC) No. 1496/2002 of 21 Aug. 2002 (amending Annex I and Annex II), O.J. Eur. Comm. L 225/13, 2002 WL 1926089, 22 Aug. 2002

${ }^{72}$ See Kevin M. Clermont, Jurisdictional Salvation and the Hague Treaty, 85 Cornell L. Rev. 89, 111-115 (1999).

${ }^{73}$ See Kevin M. Clermont, A Global Law of Jurisdiction and Judgments: Views from the United States and Japan, 37 Cornell Int'l L.J. 1, 16-18 (2004).

${ }^{74}$ See Arthur Taylor von Mehren, Theory and Practice of Adjudicatory Authority in Private International Law: A Comparative Study of the Doctrine, Policies and Practices of Common- and Civil-Law Systems, 295 Recueil des cours 9, 30-36 102-115 (2002) (viewing power as the U.S. justification for the exercise of adjudicatory authority). 
the civil law's emphasis on the forum's required connection to the claim. ${ }^{75}$

Is a jurisdictional law's origin in power, rather than in some more pt, an essential difference between the United " arguments.

Firs a reason for continued existence as First, pow. law. Far from being some Hobbesian authorization of part of U.S. law. Far from being some Ho U.S. approach, we do not governmental authority essential to the U.S. appro U.S. Supreme really know where the power test came from. The U.S. Supreme Court has never even settled on the function it is to serve. Its rationale has changed with time from an arid sovereignty theory to an allocation and then to a redundant fairness concern.

The principal thrust of America's power theory was never authointing delineation of the outer bounds of rization but, instead, a limiting delineation of the outer justify nonrecognition of judgments of foreign courts lacking jurisdiction. More significantly, though, courts used the theory to impose self limitation, to specify when the sovereign should choose not to its aw 列 force to adjudicate any dispute when and on the capability to enforce its adjudication on persons and things over which it eventually acquired physical power. That is not how sovereigns acted, though. Jurisdictional law was a limit on how far the exercise its existing power, a limit in the hope that other sovereigns would restrain incesilarly but, also, increasingly with the intuition that themselves similarly but, In other words, the power theory never such restraint was fair. In other wored

Problems, Common Ground, and First

${ }^{75}$ See, e.g., Ronald A. Brand, Current Problems, Common Ground, and First Principles: Restructuring the Preliminary Draft Convention Text, in A -93 (John J. of Jurisdiction and Judgments: Lessons from The Hague 3, 75, 88-93 (John The Barceló III \& Kevin M. Clermont eds., 2002) (arguing for the defendant-focus). The fact is that the Brussels I Regulation seldom overlooks completely the defendant's fact is that the claim's connection. See interest, and the United States sometion and the Hague Treaty, 85 Cornell L. Kevin M. Clermont, Jurisdictional Salvation and the Haintiff doctrine, privity, and Rev. 89, 96 n.38 (1999) (discu

class actions under U.S. law).

${ }^{76}$ The U.S. Supreme Court adopted an existing power test in Pennoyer vaffer $\mathrm{v}$ 95 U.S. 714, 24 L. Ed. 565, 1877 WL 18188 (1877) (overruled in part by, Shaffer v. Heitner, 433 U.S. 186, 97 . Conception of rests in fog. Compare James Weint Judicial Jurisdiction in $19 t h$ Century America, Uuber's De (crediting its genesis to the seventeenth-century Dutch theoment of Judicial JurisConflictu Legum of 1684), with Harold L. Korn, The Developm (1999) (more credibly Conflitu Lev. 935 (1999) (more credibly diction in the Unality of the American heresy). label for jurisdictional actualities. Accordingly, power was never the true rationale of American jurisdiction in any realistic sense. The true rationale was always the desirable allocation of jurisdictional authority. ${ }^{77}$

With time, American courts came to think openly of power as a label, albeit an odd one, for the rough pursuit of some unclear notion of reciprocal sovereignty. State 1 would not reach far into State 2's domain in exchange for State 2's restraint in analogous cases. The rationale thus became more instrumentalist, aimed directly at a desirable allocation of jurisdiction. ${ }^{78}$ The U.S. Supreme Court, with instrumentalist motives, was forcing this allocation on the states.

Eventually, however, the U.S. Supreme Court explicitly abandoned this instrumentalist rationale of jurisdictional allocation, ruling that sovereigns' interests do not reside in the due process clauses or in the jurisdictional doctrine, which after all the defendant might elect not to raise. Instead, the court shifted the due process power test onto the defendant's liberty interest in not being subject to the illegitimate power of a sovereign foreign to the defendant. ${ }^{79}$ The continuing difficulty is that the power test as now applied does not try to map the liberty interest's limits on that sovereign power over the defendant, whatever they might be. Instead, the power test requires the defendant's tacit consent to jurisdiction and tends to find this consent where fair. ${ }^{80}$ The power test seems ill-designed to serve such a fairness rationale. A reasonableness test would serve it more clearly. In the course of evolution, the power test has lost its raison d'être, and so the time is ripe for jettisoning it

Second, the difficulties inherent in the power test's application are numerous, as I have catalogued elsewhere. ${ }^{81}$ Most prominently, the power test remains indefinable and, hence, difficult to apply. It

${ }^{77}$ See Andrew L. Strauss, Where America Ends and the International Order Begins: Interpreting the Jurisdictional Reach of the U.S. Constitution in Light of a Proposed Hague Convention on Jurisdiction and Satisfaction of Judgments, 61 Alb. L Rev. 1237, 1250-1263 (1998); James Weinstein, The Federal Comm Origins of Judicial Jurisdiction: Implications for Modern Doctrine, $90 \mathrm{Va}$. L Rev. 69 (2004)

${ }^{78}$ See World-Wide Volkswagen Corp. v. Woodson, 444 U.S. 286, 291-294, 100 S. Ct. 580, 62 L. Ed. 2d 490 (1980).

${ }^{79}$ See Insurance Corp. of Ireland, Ltd. v. Compagnie des Bauxites de Guinee 456 U.S. 694, 702 and n. 10, 102 S. Ct. 2099, 72 L. Ed. 2d 492, 34 Fed. R. Serv. $2 d$ 1 (1982) ([t]he jurisdictional requirement "represents a restriction on judicial power not as a matter of sovereignty, but as a matter of individual liberty.").

${ }^{80}$ See Wendy Collins Perdue, Personal Jurisdiction and the Beetle in the Box, 32 B.C. L. Rev. 529, 534-550 (1991).

${ }^{81}$ Kevin M. Clermont, Jurisdictional Salvation and the Hague Treaty, 85 Cornell L. Rev. 89, 99-104 (1999). 
never succeeded in producing exclusive jurisdiction. As the power

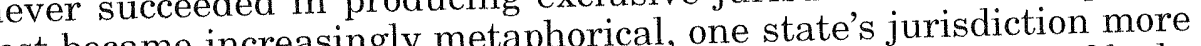
列 evidently came to overlap other states jurisdiction. Instead of looking only to physical presence, courts looked to the in-state effects of the defendant's acts or even to the quality and nature of the act. Ultimately the U.S. Supreme Court has come to require "a sufUltimately, the forum State to ficient connection between the dorum." 82 Whether make it fair to require defense of the action in the for it is "fair" to exercise power over the defendant will come to turn on the interests of others, and so the power test is inevitably eroding into a reasonableness test.

In sum, the power test remains only a complicated way station on the road to a better law of jurisdiction for the United States; it is not an essential feature.

\section{Effect of constitutionalization}

A distinctive feature of U.S. jurisdictional law is the prominence A the Constitution in the development and content of that law. ${ }^{83}$ of the Constites Ever since the U.S. Supreme Court anchored the lim the due process clause of the Fourteenth Amendment, ${ }^{84}$ the Constitution has reigned in the foreground. Currently, the due pro cess clauses put an outer limit on the list of state and federal forums with territorial authority to adjudicate litigation with non-local with inappropriate, indeed, that it is not fundamentally unfair.

Again, however this is not an essential difference between U.S. uropean Union approaches. First, Europeans impose a not issimilar outer limit through non-constitutional means, such as by aplying European texts to limit jurisdiction or by applying directly various European texts to lim to recognizing and applying indirectly a public-policy exception to rimit enforcing foreign judgments. Second, the outer lime and an evolving one; it

${ }^{82}$ Kulko $v$. Superior Court of California In and For City and County of San ${ }^{82}$ Kulko v. Sussibly, "fair" Francisco, 436 U.S. 84, 91, 98 S. Ct. 1690,56 L. Ed. 2 d 132 (1978) defendant's tacit in this case's language could be read narrowly to invoke only the defendant availconsent embodied in power's requirement of the defendant's "purposeful avallment" of the benefits and protections of the forum's laws. See Hanson v. Denckla,

${ }^{83}$ See Patrick J. Borchers, Comparing Personal Jurisdiction in the United Sommunity: Les States and the European Community:

${ }^{84}$ Pennoyer v. Neff, 95 U.S. 714, 24 L. Ed. 565, 1877 (186, 97 S. Ct. 2569, 53 L. Ed. 2 d 683 (1977)).

${ }^{5}$ See Nikitas Hatzimihail \& Arnaud Nuyts, Judicial Cooperation Between the United States and Europe 6 (May 12, 2003) (manuscript on file with author) United States and Turisdiction in the United would become even more generous with the abolition of the power test. Third, the extensive set of U.S. statutes and doctrines on selfrestraint reflects the propriety of subconstitutional law on jurisdiction. Just as in Europe, a second level for regulating jurisdiction exists in the United States, and this regulation can be in the form of rules. There is, thus, no impediment to U.S. lawmakers' reasserting themselves by making jurisdictional law inside the currently generous constitutional limit. Indeed, such reassertion is the only path open to improving U.S. jurisdictional law.

The well-known failures of the current law flow from the U.S. Supreme Court trying to do too much in shaping that law out of the few bare words of the Constitution. Nothing in the court's raw materials - the constitutional language, subject to judicial interpretation-can generate a set of jurisdictional criteria that would be both certain and sensible. The U.S. Supreme Court should therefore recognize its own limitations. The Court should continue playing its role in policing the subordinate systems' excesses in extending their reach, but should withdraw from the task of actually allocating jurisdictional authority. The former of these two roles conforms to the traditional and proper one for the Court in applying the due process clauses, while the latter task seems more legislative in nature and in need of the legislatures' capabilities. In other words, the Court should leave to other lawmakers the task of narrowing the choice among reasonable forums.

If these other lawmakers stepped up to perform this task, then the constitutional limit could fade into the background, becoming not only a nonessential feature but also an unimportant one. We could thereby achieve the optimal law on territorial authority to adjudicate: a law under which the constitutional limit fades into the background and subconstitutional provisions move to the fore.

\section{Primacy of judiciary}

Whatever real differences exist more generally between the roles of common-law and civil-law judges, U.S. courts have been relatively active in shaping jurisdictional law in particular. ${ }^{86}$ Alternatively stated, the U.S. trusts its courts and relatively mistrusts its

in Europe Compared, $\S 3$ (emphasizing the fair trial doctrine of the European Convention on Human Rights art. 6). Compare Charles T. Kotuby, Jr., Internal Developments and External Effects: The Federalization of Private International Law in the European Community and Its Consequences for Transnational Litigants, 21 J.L. \& Com. 157, 164-167 (2002) (discussing the European Court of Justice's Group Josi case, which applied the Brussels Convention's limitations to a non-European plaintiff')

${ }^{86}$ See Arthur Taylor von Mehren, Theory and Practice of Adjudicatory Authority in Private International Law: A Comparative Study of the Doctrine, Policies and Practices of Common- and Civil-Law Systems, 295 Recueil des cours 9, 72-73, 95 (2002); Patrick J. Borchers, Comparing Personal Jurisdiction in the United 
legislatures, while Europe places its trust conversely. This contextual difference has had significant effects on that jurisdictional law's development and content. The reason is that judges tend to extend their focus beyond any jurisdictional rules in place, looking both up toward first principles and also down toward messy facts.

Still, a somewhat enlarged judicial role does not amount to an essential difference from the European approach to jurisdiction. Consider the reasons that this difference is not an ineradicable difference. First, the difference is again not day-and-night. The difference. First, the difference is a justice is playing an increasingly key role on its side $^{87}$ Meanwhile, the active role of U.S. courts would naturally diminish as the constitutional tests retreated into the background diminish as the constitutional tests retreated into the background and as subconstitutional law emerged in their place, as proposed above; that is, U.S. courts would no longer have to play on a daily basis their key role of constitutional interpretation. Second, the subconstitutional law should come by legislation, not by judicial action. Traditionally, even in the United States, legislatures have played the dominant role in writing the subconstitutional jurisdictional and venue law, utilizing their superior capabilities to investigate social problems and then draft comprehensive and detailed provisions. Case-by-case adjudication is obviously a mechanism unsuited to generating the basic law here. Normally, courts cannot or do not use even their rulemaking power to treat this subject. Legislative action therefore is the preferred route to U.S. reform. Third, after such reform the courts must cooperate by treating the statutes' words as if they mean something. Courts must ing the statutes word by ad-hoc and result-oriented stretching that would undo those legislative moves toward certainty and restraint.

It is true that U.S. legislatures and courts have not done a good job in the past. The legislatures have mainly abdicated, relying on the Constitution and the courts to supply the bulk of the law on territorial jurisdiction. For example, many long-arm statutes expressly incorporate by reference the constitutional tests. The other longarm statutes require active judicial interpretation, and most often arm statutes requiric guidance they the courts have managed to strip them of any specific guidance they

States and the European Community: Lessons for American Reform, $40 \mathrm{Am}$. J Comp. L. 121, 153 (1992).

${ }^{87}$ See Christian Kohler, Beyond Brussels: The Wide Reach of the European Court's Case-Law on the Jurisdiction and Judgments Convention, this volume, chapter 11 . jurisdictional law all too often. ${ }^{88}$ Legislatures, on both the state and the federal level, could undertake a much more serious effort expressly to site cases in convenient, efficient, and otherwise desirable courts than they have hitherto. ${ }^{89}$ Moreover, U.S. courts are capable of playing the subsidiary role of rule-applying, as they do in many areas of the law, and even in regard to jurisdiction in some states. $^{90}$

\section{Absence of rules}

Relatively speaking, the United States does emphasize the role of fact-specific inquiry in matters of jurisdiction:

The civil law system simply attempts to identify in advance an appropriate nexus for asserting jurisdiction in most cases, but with full awareness that such nexus may be less proper in some cases. This is a deliberate policy choice in favor of legal certainty and the speedy resolution of preliminary jurisdictional issues, perhaps at the expense of individual equity.

Compared to this clear, yet flat and non-distinguishing Continental attitude, the elaborate American search for sufficient contacts appears as an overwhelming concern for individualized justice, even at the expense of certainty and predictability . . . American notions of establishing adjudicatory jurisdiction invite a scrutiny of defendants and causes of action on a case-by-case basis and in a manner not disassociated from a contemplation of the merits. ${ }^{91}$

Another way to phrase this difference is that the United States has

${ }^{88}$ See Douglas D. McFarland, Dictum Run Wild: How Long-Arm Statutes Extended to the Limits of Due Process, 84 B.U. L. Rev. 491 (2004) (criticizing this approach).

${ }^{89}$ If the state legislatures prove reluctant to rejn in their own courts, then Congress could, but unlikely would, intercede by utilizing its constitutional powers to legislate general limits on the states' interstate and international reach. For an attempt at drafting such a statute, see Kevin M. Clermont \& Kuo-Chang Huang, Converting the Draft Hague Treaty into Domestic Jurisdictional Law, in A Global Law of Jurisdiction and Judgments: Lessons from The Hague 191, 226-228 (John J. Barceló III \& Kevin M. Clermont eds., 2002). Compare Linda e. Silberman \& Andreas F. Lowenfeld, A Different Challenge for the ALI: Herein of Foreign Country Judgments, an International Treaty, and an American Statute, 75 Ind. L.J. 635 (2000) (advocating a federal statute to govern the recognition and enforcement of foreign judgments in the United States).

${ }^{90} \mathrm{New}$ York courts have respected their long-arm statute, while some other states' courts have freely reworked theirs. Compare Longines-Wittnauer Watch Co. v. Barnes \& Reinecke, Inc., 15 N.Y.2d 443, 261 N.Y.S.2d 8, 209 N.E.2d 68, 24 A.L.R.3d 508 (1965), with, e.g., Gray v. American Radiator \& Standard Sanitary Corp., 22 I11. 2d 432, 176 N.E.2d 761 (1961). See generally Richard H. Field, Benjamin Kaplan \& Kevin M. Clermont, Materials for a Basic Course in Civil Procedure 518-531 (8th ed. 2003) (comparing states' different approaches).

${ }^{91}$ Konstantinos D. Kerameus, A Civilian Lawyer Looks at Common Law Procedure, 47 La. L. Rev. 493, 497 (1987). See Tapio Puurunen, The Judicial Jurisdiction of States over International Business-to-Consumer Electronic Commerce from the Perspective of Certainty, 8 U.C. Davis J. Int'l L. \& Pol'y 133, 241-249 (2002). 
handled jurisprudence's fundamental, and unavoidable, tension between certainty and precision in a way that unduly favors 列 proaches to jurisdiction is indeed a big one.

There is nothing inevitable about the route chosen by the United States, though. Its law strikes the certainty/precision balance differently in areas other than jurisdiction. Its chosen route for jurisdiction could undergo rethinking, as the legislatures undertake the the focal task of constructing subconstitution legislatures should issue could be phrased in terms of whether the legislatures should they accomplish the act by rules or by standards, that is, should they accomplish the limiting of forum-choice by a set of preconceived legislative rules that would rigidly treat categories of cases or by a delegation to the courts via a standard with a list of factors that would permit factspecific analysis individualized to the case? The latter route can be co leading to a tiny list of available forums, but at the more precise, leading decision in many cases. The considerable cost of difficult judicial decision in many cases. The expense of seeking a very good court does not seem like a socially productive way to spend money, at least when compared to other prefording choice of forum and of law. In contrast, possible refor some certainty and it seems more neutral in application by the crafting ules in advance. Europeans have rightly opted to take thules in advance. Europeans have right the rule route.

\section{Role of discretion}

ing their allegiance to case-specific fairness, S courts see nothing particularly troubling in discretionarily declining jurisdiction in order to shift the litigation to a more appropriate forum and thereby fine-tune an otherwise overbroad (1) ${ }^{93}$ Europeans, by contrast, very much view jurisdictional provisions as mandatory, detesting discretion in their genral provisions on territorial authority. ${ }^{94}$ "The approaches of the on territorial authority.

${ }^{92}$ See Arthur Taylor von Mehren, Theory and Practice of Adjudicatory AuthorSee Arthur Tay ity in Private International Law. A Comparstems, 295 Recueil des cours 9,68 and Practices of Common- and Civil-Law Sysions (2002) ("two sets of basic policies control the design of jurisdictionability on the plicable to multistate litigation: one hand litigational fairness, on the other")

${ }^{93}$ Arthur Taylor von Mehren, Theory and Practice of Adjudicatory Authority Prive Study of the Doctrine, Policies and in Private International Law: A Com Sytems, 295 Recueil des cours 9, 306--308, Practices of Common- and Civil-Law Systems, 295 Recueil des cou 399-401 (2002)

${ }^{94}$ See Mathias Reimann, Conflict of Laws in Western Europe, 83-85 (1995) law's rejection of forum non conveniens); Stephen B. Burbary or Beginning of the Mil- a distinctive legal history, and also reflect to some extent cultural differences." "95

Of course, Europeans may detest explicit discretion in jurisdiction, but they implicitly exercise discretion by creative judicial construction of code provisions, "a little like Monsieur Jourdain in Le Bourgeois Gentilhomme who spoke prose without knowing it."96 Likewise, refusing to choose, U.S. legal systems take both routes. They mainly rely on provisions affirmatively siting litigation, which range from a basic venue statute (which generally site litigation where the defendant resides or "a substantial part of the events or omissions giving rise to the claim occurred"97) to the judicially created and obscure local-action doctrine (involving claims that supposedly could take place only in one locale ${ }^{98}$ ); but they also expressly give a role to discretionary declination via the transfer-of-venue provision $^{99}$ and the forum non conveniens doctrine. ${ }^{100}$

Here the legal systems do not really differ on fundamentals and, indeed, both European and American instincts are probably correct. Legislative rules should be the dominant motif, but there will irresistibly be a small residual role for judicial discretion to decline jurisdiction, in adjusting the demands of the rare case to the rigid rules. That residual role should be an express one, as the Americans would argue, because openness allows control; but the role should be a small one, as the Europeans would argue. For the United States, the role could shrink ever smaller as its rules, as proposed below, became more restrained, giving the plaintiffs less jurisdictional excess to play with.

\section{Recasting U.S. law}

Any legal system's task is to site litigation in a fashion that puts appropriate constraints on the litigators' gaming and the system's

lennium?, 7 Tul J. Int'l \& Comp. L. 111; 117-118 (1999); Russell J. Weintraub, How Substantial Is Our Need for a Judgments-Recognition Convention and What Should We Bargain Away to Get It?, 24 Brook. J. Int'l L. 167, 210-211 (1998).

${ }^{95}$ Arthur Taylor von Mehren, Theory and Practice of Adjudicatory Authority in Private International Law: A Comparative Study of the Doctrine, Policies and Practices of Common- and Civil-Law Systems, 295 Recueil des cours 9, 400 (2002) (quoting Airbus Industrie GIE v. Patel, [1999] 1 A.C. 119, 131, 1998 WL 1043848 (Hu 1998)).

${ }^{96}$ Catherine Kessedjian, Judicial Regulation of Improper Forum Selections, in International Dispute Resolution: The Regulation of Forum Selection 273, 290 (Jack L. Goldsmith ed., 1997).

${ }^{97} 28$ U.S.C.A. $\$ 1391$.

${ }^{98}$ See Livingston v. Jefferson, 15 F. Cas. 660, No. 8411 (C.C.D. Va. 1811) (trespass to land)

${ }^{99} 28$ U.S.C.A. $\$ 1404(\mathrm{a})$

${ }^{100}$ See Piper Aircraft Co. v. Reyno, 454 U.S. 235, 102 S. Ct. 252, 70 L. Ed. 2d 419, 1982 A.M.C. 214 (1981). 
verreaching. Differences in performing that task do exist between the United States and the European Union, but the differences are the sense of bridgeability. I maintain that both the United States and the European Union could improve by moving to optima nearer the center.

It may very well be that the United States would have to move rther to optimum. What would that reformed U.S. law (1) What would that reformed U.S. law look like? This inquiry should proceed on constitutional and look lis. The Constitution puts an outer limit on subconstitutional the list of available forums with territorial authority to adjudicate litigation with non-local elements, but its minimal requirements produce a list of forums that is too long to be optimal or even acceptable as the sole limit. The U.S. legal systems therefore must utilize the various strands of subconstitutional law to narrow the list not necessarily to the best forum but at least to a shorter list of appropriate forums.

\section{Constitutional limit}

a the outer limit, currently comprising power and unreasonableness tests but, more ideally, contracting pow though change over time is a ing to a reasonableness test. Even though change over time is a certainty, constitutional reform normally must be expressed more as a hope than as a proposal. So here it would be appropriate to pass quickly to the shaping of an optimal jurisdiction and venue scheme on the subconstitutional level.

Nevertheless, before doing so, a few words on the supposed lack limit are in order. It is a common constitutional law in this area is too vague and criticism that the constitutiona that nothing can be done about that flaw. So, is the constu the evil limit of due process-current or future-fatally infected by the evi of uncertainty? No, for five reasons:

(1) we should always bear in mind that complete certainty in law is unachievable, and we should remember that certainty is never the only goal of a legal provision;

(2) we should acknowledge that the uncertainty of this constitutional law is not all that severe. The U.S. courts through their many decisions on territorial authority have given it definite meaning in all but unusual cases;

(3) I must admit that I find unfounded and even naive the suggestion that European law on jurisdiction has achieved suggestion that European law on jurisdiction has achieved markedly greater certainty than U.S. law. ${ }^{101}$ This suggestion is improbable on its face. The Brussels regime attempts to satisfy and reconcile the needs of a variety of dif-

${ }^{101} \mathrm{E}$ g. Patrick J. Borchers, Comparing Personal Jurisdiction in the United States and the European Community: Lessons for American Reform, 40 Am. J Comp. L. 121, at 122, 146 (1992); Friedrich Juenger, Judicial Jurisdiction in the ferent countries and legal systems, using vague and simple formulas sometimes foggily drafted and always in multiple languages. It necessitates the complicated interplay of European Union and national laws. In application, the picture is no prettier. The Brussels regime operates without the benefit of a great deal of authoritative clarifying case law. There is still a lot of litigating in the European Union about where to litigate. ${ }^{102}$ So Europe is nowhere close to the perfect-certainty end of the spectrum running from uncertainty to certainty. It may be that the European Union enjoys somewhat greater certainty in its jurisdictional law but, in fact, the United States is not really that far behind;

(4) most importantly, we should recognize the restricted role of the U.S. Constitution here, a role that does not require certainty. It is a constitutional limitation, after all. Its role is to serve as an outer limit preventing jurisdictional excess in special and unforeseeable circumstances. Its function is as a backup test to block jurisdiction when, in a particular case, the rules in place would otherwise permit a fundamentally unfair exercise of jurisdiction. It thereby protects outsiders from exorbitant jurisdiction, and so in theory should be needed only rarely. It is an outer limit also in the sense that courts should not in theory be routinely exercising a reach all the way to the limit of due process, just as we do not punish to the very limit of cruel and unusual punishment. The law should operate within and safely distant from the outer limits; thus, the constitutional tests should not be in routine use; and

(5) I might go so far as to argue that certainty in this constitutional limit on territorial jurisdiction is not even desirable. It should be a flexible outer limit; flexible application should be its hallmark, as it must apply to cases in-between general and specific jurisdiction, apply across a range of defendants' state-directed activities, and apply in light of the effects of a particular lawsuit on the defendant. It also has to apply in unforeseeable circumstances, and it needs to relax or tighten in response to socio-economicpolitical pressures and technological and philosophical changes.

United States and in the European Communities: A Comparison, 82 Mich. L. Rev. 1195, 1207-1209 (1984).

${ }^{102}$ E.g., BL Macchina Automatiche SpA v. Windmoller \& Holscher KG, [2004] I.L. Pr. 19 (It. Cass., 26 Nov. 2003) (holding no Italian jurisdiction under Brussels I Regulation art. 5(3) for action by Italian company against a German company for declaration of noninfringement of defendant's patent for bagging machines) See C.G.J. Morse, International Shoe v. Bruscels and Lugano: Principles and Pitfalls in the Law of Personal Jurisdiction, 28 U.C. Davis L. Rev. 999, 1012-1025 (1995). 
After all, jurisdictional problems remain problems because they are hard problems. A nice way to demonstrate this point is to are hassically unclear cases from reconsider comparatively two of the classically unclear cases from
the U.S. Supreme Court: World-Wide Volkswagen Corp. v. Woodson $^{103}$ and Asahi Metal Industry Co. v. Superior Court. ${ }^{104}$

In World-Wide, which supposedly engendered a jurisdictional law that is "a hopeless mess," "105 the Court made the close call that Oklahoma did not have constitutional power over New York car dealers if the plaintiff drove the car to Oklahoma and had a horrific accident there, because the defendants had not conducted sufficient accident there result would be dif-

${ }^{103}$ World-Wide Volkswagen Corp. v. Woodson, 444 U.S. 286, 100 S. Ct. 580, 62 Ed 2 or $490(1980)$. While passing through Oklahoma on a move from New York L. Ed. 2d 490 (1980). While passing through Okardered burns allegto a new home in Arizona, plaintfors had a car accident. They sufferedized in edly resulting from their car's defective design. While still hospitalized in OKlahoma, they sued in state court there. They included as defendants the regional wholesale distributor for New York, New Jersey, and Connecticut and the retail dealer from whom they had bought the car in New York, both those defendants bedeal in ing ing selling the car involved in two defendants' this accident. The U.S. Supreme Court held against jurisdiction ovich therefor defendants. They did not have minimum contacts with Oklahoma, which therefore had no power over them. Admittedly, one could argue that these defendants sell cars predictably to be used in Oklahoma, plaintiffs have an interest in litigating at the scene of the accident, and Oklahoma has an interest in enforcing its highway the safety laws, and cow reasonableness is irrelevant if there is no power.

${ }_{104}$ Ani Metal Industry Co., Ltd. v. Superior Court of California, Solano ${ }^{104}$ Asahi Metal Industry Co., Ltd. v. Superior Court of Ciab. Rep. (CCH) P County, 480 U.S. 102, 107 S. Ct. 1026, 94 L. Ed. $2 d$ 92, Prod. Liab. Rep ion power 11267 (1987). In this case, the U.S. Supreme Court split on the question of powrisin the stream-of-commerce context, with a minority arguing that, to bestow juet in diction, the manufacturer must have had an active purpose to serve the market in the forum state where the product was sold. That case's actual holding, however, was that regardless of power, jurisdiction in California was unreasonable because was that regard facts: the state could not inflict on a Japanese valve manufacturer of the unusual facts: the state claim by a Taiwanese tire-tube the burden of defending this third-party claim had settled and neither the manufacturer, when the main product liability claim had settests in sustaining juTaiwanese defendant nor the forum state had adequate interests in sustaining the risdiction for the remaining indemnity claim. Given this ambiguous guidane, the lower courts are now shaping a new consensus that only slightly shortens the prior jurisdictional reach down the stream of commerce. Their decisions currently appuris in burchaser's state has power over a pear split, but the bethere and that seller with an actual awareness of its products being reguable. See Russell J. such personal jurisdiction normally will not be . Cf. Larry L. Teply \& Ralph U. Whitten, Civil ProceRev. $531,533,5$ plaintiff dure 239 (2d ed.

${ }^{105}$ Patrick J. Borchers, Comparing Personal Jurisdiction in the United States and the European Community: Lessons for American Reform, 40 Am. J. Comp. L. $121,143(1992)$ ferent under Brussels I's tort jurisdiction "where the harmful event occurred." 106 The European Union achieved that "clear" result only after suffering through judicial creation of redundant jurisdiction at the places of act and of injury, as well as having addressed such questions as whether product liability actions involve tort or contract, whether such harm is sufficiently direct, and whether supranational or national law governs such issues. ${ }^{107} \mathrm{I}$ further think that without the power test, the U.S. Constitution, like the European Union's law, would allow jurisdiction in the World-Wide setting (and properly so).

The European Union's relative clarity starts disappearing as one wades deeper into stream-of-commerce cases, such as Asahi. There, the U.S. Supreme Court made the close call that California's exercise of jurisdiction was constitutionally unreasonable in the peculiar circumstances involving a stranded third-party claim by a Taiwanese manufacturer against a Japanese supplier. Curiously, on the case's actual facts involving a claim that happened to arrive by third-party procedure, jurisdiction would clearly exist by virtue of Brussels I's juridiction dérivee; ${ }^{108}$ but that result is clarity by fluke and it is not necessarily a desirable outcome. ${ }^{109}$ Consider instead the more general situation of the tort victim suing the Japanese supplier. Although jurisdiction at the place of a sufficiently direct tortious harm would seem to exist under the words of Brussels $I,{ }^{110}$ I do not know what the European Court of Justice would actually do with regard to the stream of commerce as it dilutes in

${ }^{106}$ Brussels I Regulation, art. 5(3); see Ronald A. Brand, Tort Jurisdiction in a Multilateral Convention: The Lessons of the Due Process Clause and the Brussels Convention, 24 Brook. J. Int'l L. 125, 152 (1998).

${ }^{107}$ See Patrick J. Borchers, Comparing Personal Jurisdiction in the United States and the European Community: Lessons for American Reform, $40 \mathrm{Am}$. J. Comp. L. 121, 144-146 (1992) (discussing the European Court of Justice's Mines de Potasse, Kalfelis, and Dumex Batiment cases).

${ }^{108}$ Brussels I Regulation, art. 6(2) (extending jurisdiction to third-party defendants). See Russell J. Weintraub, A Map Out of the Personal Jurisdiction Labyrinth, 28 U.C. Davis L. Rev. 531, 550-551 (1995).

${ }^{109}$ Compare Kevin M. Clermont, Jurisdictional Salvation and the Hague Treaty, 85 Cornell L. Rev. 89, 96-97 (1999), with Kevin M. Clermont \& Kuo-Chang Huang, Converting the Draft Hague Treaty into Domestic Jurisdictional Law, in A Global Law of Jurisdiction and Judgments: Lessons from The Hague 191, 213-217 (John J. Barceló III \& Kevin M. Clermont eds., 2002).

${ }^{110}$ See Linda J. Silberman, Judicial Jurisdiction in the Conflict of Laws Course: Adding a Comparative Dimension, 28 Vand. J. Transnat'l L. 389, 401-02 (1995); Russell J. Weintraub, How Substantial Is Our Need for a Judgments-Recognition Convention and What Should We Bargain Away to Get It?, 24 Brook. J. Int'l L. 167,191 (1998). 
this way. ${ }^{11}$ Some European Union countries' national law might view such jurisdiction, without any sort of foreseeability condition, as exorbitant. ${ }^{112}$ The current U.S. approach seems about as clear as the European Union approach, while both stumble toward permitting foreseeable, and only foreseeable, jurisdiction in this general stream-of-commerce situation (and properly so).

In short, the Constitution is not the place to seek certainty. We should seek certainty - and provide the necessary and appropriate degree of fair warning and predictability-by subconstitutional regulation inside the constitutional outer limit. In concrete terms, lawmakers should specify that venue lies only in the more convenient, efficient, and otherwise desirable of all the forums not fundamentally unfair.

\section{Subconstitutional limits}

A good law of territorial authority to adjudicate, then, would have subconstitutional provisions actively restricting forum selection inside the constitutional limit-or, in other words, it would have a rational law of venue, broadly defined, that incorporates and revamps today's subconstitutional jurisdiction law as well as all the revamps today's subconstitutional jurisdiction to be venue-like. What form and content should the legal system give to this law of venue? As explained above, legislative action is the preferred route to domestic reform, and general rules should be the dominant motif, although there will irresistibly be a small residual role for discretion in adjusting the demands of the rare case to the rigid rules. Preferably after wiping the jurisdiction and venue slate clean of its current mélange-discarding, for example, the patchwork of special venue statutes and the local-action doctrine-the replacement statutes should set out rules expressly phrased in the language of venue. Such statutes should site cases usually at the defendant's habitual residence or where a specific part of the events in the suit occurred. This is the field on which the lawmakers should engage the policy battles that must precede optimizing venue, be they fought along plaintiff/defendant, individual/business, or liberal/ conservative axes. The statutes should state their resolutions in terms that embrace a rules-based approach to territorial authority

\footnotetext{
${ }^{111}$ See Ronald A. Brand, Tort Jurisdiction in a Multilateral Convention: The Lessons of the Due Process Clause and the Brussels Convention, 24 Brook. J. Int' L. 125, 145-154 (1998).

${ }^{112}$ See Tapio Puurunen, The Judicial Jurisdiction of States over International Business-to-Consumer Electronic Commerce from the Perspective of Certainty, 8 U.C. Davis J. Int'l L. \& Pol'y 133, 252 (2002) (e-torts). Compare Catherine Kessedjian, International Jurisdiction and Foreign Judgments in Civil and ComKessedjian, International Jurisdiction. Doc. No. 7, 70-72, 82 (Apr. 1997) (discussing desirable treaty provision).
}

to adjudicate, resisting the allure of individualized fact-specific analysis. The statutes should thus nudge the law along the spectrum toward certainty, giving outsiders clearer guidance on what activities will and will not subject them to local suit. If the United States, on both the state and the federal level, were to undertake the other parts of the reform that I have suggested-eliminate the power test, push the constitutional reasonableness test into the background, rely less on the judiciary, and downplay the role of discretion-its jurisdictional law could indeed become somewhat more certain.

Furthermore, the new legislation should move toward greater restraint as well as greater certainty. Because the choice of forum importantly affects a case's outcome and because currently the plaintiff has a wide choice and, in fact, has too much opportunity to shop for a favorable forum, the lawmakers should take a more restrictive approach to territorial authority to adjudicate. Now, a question remains whether the system should aim for a short list of appropriate forums or aim for allocating the case to the best forum. It is conceivable that some sort of "law of forum conveniens" be developed to route cases to the one right court, probably where the case primarily arose, which would then apply local law. ${ }^{114}$ Shooting for precision is terribly costly, though, ${ }^{115}$ and given the current state-federal-international institutional structure, this approach is simply not feasible. Therefore, the system should settle for a short list. This resolution reflects a policy that Professor von Mehren calls proportionality, which "seeks to ensure not only that the forums in which claims can be pursued are appropriate and sufficient in number but also, in order to deter unjustified forumshopping, no more numerous than is required to give the plaintiff, absent exceptional circumstances, a fair opportunity to litigate his cause." "116

As for fine-tuning, legislatures could retain a role for courts by authorizing them to transfer a particular case's venue in the interest of justice. For example, an excellent argument can be made in

${ }^{113}$ See Albert A. Ehrenzweig, The Transient Rule of Personal Jurisdiction: The "Power" Myth and Forum Conveniens, 65 Yale L.J. 289, 292, 312 (1956).

${ }^{114}$ See Joseph J. Kalo, Jurisdiction as an Evolutionary Process: The Development of Quasi In Rem and In. Personam Principles, 1978 Duke L.J. 1147, 1194 ("Instead, the focus should be on which forum is best qualified to adjudicate the parties' claims.")

${ }^{115}$ See David P. Currie, The Federal Courts and the American Law Institute (pt. 2), 36 U. Chi. L. Rev. 268, 307 (1969) ("It would be mellow to try every action in the most convenient forum. But deciding where that forum is costs altogether too much time and money.")

${ }^{116}$ Arthur Taylor von Mehren, Theory and Practice of Adjudicatory Authority in Private International Law: A Comparative Study of the Doctrine, Policies and Practices of Common- and Civil-Law Systems, 295 Recueil des cours 9, 68 (2002). 
favor of the current scheme of transfer of venue between federal courts, as it efficiently and fairly works to remove unjust forum advantage while leaving unchanged the applicable law. ${ }^{117}$ Forum advantage while leaving unchanged the applicable law. Forum not fit in a newly rationalized scheme. ${ }^{118}$ In brief, the rules should normally be mandatory in application.

Finally, what is the likelihood of such reform proceeding on the constitutional, legislative, and judicial levels? It is not completely a constitutional, legistathe axperiences at The Hague have had a pipe dream. First, the experiences at The Hague have had a profound educational effect on U.S. academics and policymakers. Second, global changes and the pressures for convergence are accelerating yearly. Third, if a general convention on jurisdiction or judgments were ever achieved, the need for implementing legislation in the United States would greatly foster reform along the tion in the United States would U. Supreme Court would possibly proposed lines and, indeed, the U.S. Supreme Court would possibly one that supplants the moribund power test. ${ }^{119}$

\section{Conclusion}

The natural reaction to a decade of frustration in negotiations on jurisdiction at The Hague would be now to back off from trying for international agreement on the subject. My contentions, however, are that the need for international agreement on the subject remains strong and that its feasibility increases as the U.S. posiremains strong and that its feasibility increases as the U.S. position on jurisdiction retains no essential differences from the European Union approach and is moving with time farther toward the center. Achieving agreement on jurisdiction would encourage the center. Achieving agreement on juris Exopean Union law. Jurisdiction indeed could serve as a fulcrum in rearranging the

${ }^{117}$ See Kevin M. Clermont \& Theodore Eisenberg, Exorcising the Evil of ForumShopping, 80 Cornell L. Rev. 1507 (1995).

${ }^{118}$ See Kevin M. Clermont, The Story of Piper: Fracturing the Foundation of Forum Non Conveniens, in Civil Procedure Stories 193 (Kevin M. Clermont ed. Fo04); Jeffrey A. Van Detta, Justice Restored: Using a Preservation-of-Court200 Aceess Appore Kevin M. Injury Case Studies, 24 Nw. J. Intl L. Clermont, Jurisdictional Salvation and the Hague Troty, 85 , Cor 118-121 (1999) (arguing that the United States should abandon its ardor for forum non conveniens, in response to the Europeans sharp distaste for the discretionary doctrine, in order to increase the chances of agreement on a jurisdiction-and-judoments convention), with Ronald A. Brand, Comparative Forum Non Conveniens and the Hague Convention on Jurisdiction and JudgFor

ments, 37 Tex. Int'l L.J. 467 and civil-law approaches).
and

${ }^{119}$ See Kevin M. Clermont, Jurisdictional Salvation and the Hague Treaty, 85 Cornell L. Rev. 89, 124-127 (1999); cf. Ayelet Ben-Ezer \& Ariel L. Bendor, The

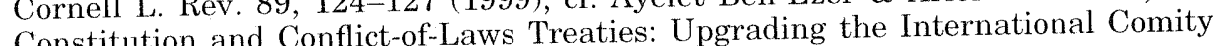
29 N.C. J. Int'l L. \& Com. Reg. 1 (2003) (more general treatment) international judicial order. I thus submit that in the not too distant future the United States and the European Union should renew the work toward a general agreement on jurisdiction.

In this article I have made suggestions on improving U.S. regulation of its own jurisdiction, but I admit to being in no position to suggest the best path to international harmonization. With the benefit of hindsight, I would minimally maintain that the United States was being unrealistic in jumping head-first into multilateral negotiations at The Hague on broad and difficult issues with expectations of quick success. Important to remember is that the Brussels Convention emerged in a region that had a long history of experimentation with bilateral and then regional treaties on judgments and later on jurisdiction. ${ }^{120}$

So I believe that, just as the United States in the 1990s should instead have taken some smaller first steps before trying to run, the world today should try to approach jurisdictional reform more modestly. Perhaps the route to a multilateral agreement should pass through bilateral or regional agreements. ${ }^{121}$ Perhaps the world should work up to a convention by first agreeing on nonbinding principles, rules, or model laws. Even before that, perhaps nations could develop their own versions of laws that could serve as models, with the United States possibly so acting initially on the state level or even through non-state actors such as the American Law Institute or the National Conference of Commissioners on Uniform State Laws.

Eventually, however, a multilateral convention would be the best route for making the final approach to jurisdictional harmonization. The alternative of nonbinding approaches has this problem: experience has proven that nations are not quick on their own to conform to international norms as to jurisdiction. By my conclusion I do not mean to say that the multilateral convention must impose strict harmonization, rather, it could deliver something like a state of approximation, via a flexible convention. One possibility would be a mixed convention, even a very loose one, which would allow an improved coexistence while jurisdictional evolution further proceeds, enabling later a closer harmonization. ${ }^{122}$ An even less daunting transitory approach would be a convention simple, in the

${ }^{120}$ See Samuel P. Baumgartner, The Proposed Hague Convention on Jurisdiction and Foreign Judgments, 54-66 (2003).

${ }^{121}$ See Kevin M. Clermont, A Global Law of Jurisdiction and Judgments: Views from the United States and Japan, 37 Cornell Int'l L.J. 1, 24-26 (2004).

${ }^{122} \mathrm{~A}$ mixed convention, as distinguished from a double convention, is a way to bridge the current differences on jurisdictional approaches. A mixed convention includes not only a so-called whitelist of required jurisdictional bases and a socalled blacklist of prohibited bases, like a double convention, but also a catchall gray zone of permitted bases. In the gray zone, a signatory country could exercise 
form of a judgments convention that would control jurisdiction only indirectly. ${ }^{123}$ Whatever the chosen route to reform, I recognize that, as the negotiators like to say, it will require persistence, pragmatism, and patience.

jurisdiction on any basis under its own law not on the blacklist or whitelist, but other countries would not have to recognize or enforce the resulting judgment. Although such a mixed convention does not go as far in providing global uniformity as a double convention, its more limited ambition greatly facilitates international agreement. It also provides a means to handle jurisdiction in areas where diversity of practice is beneficial at present or where significant changes are foreseeable in the near future. See Ronald A. Brand, Community Competence for Matters of Judicial Cooperation at the Hague Conference on Private International Law: A View from the United States, 21 J.L. \& Com. 191, 195-197 (2002).

${ }^{123}$ See Arthur T. von Mehren, Enforcing Judgments Abroad: Reflections on the Design of Recognition Conventions, 24 Brook. J. Int'l L. 17, 29 (1998). 